\title{
Effect of a side chain rotaxane structure on the helix-folding of poly $(m$-phenylene diethynylene)
}

\author{
Sakiko Suzuki, Kazuki Matsuura, Kazuko Nakazono and Toshikazu Takata
}

Poly ( $m$-phenylene diethynylene) tethering a pendant rotaxane switch was obtained by the $\mathrm{CuCl}(\mathrm{I})-\mathrm{O}_{2}$ oxidative coupling polymerization of the corresponding $m$-diethynylphenyl monomer. The polymerization produced poly( $m$-phenylene diethynylene) with a high molecular weight and with a good yield of amine-type rotaxane side chains. Treatment of the polymer with trifluoroacetic acid gave the ammonium salt-type rotaxane side chain with a switch in the position of the wheel component. This positional change was reversed by treatment with 1,8-diazabicyclo[5.4.0]undec-7-ene. The dynamic folding of the polymer was confirmed by UV-Vis spectroscopic analysis. The amine-type polymer favored a folded conformation stabilized by the intramolecular $\pi-\pi$ interaction of the main chain in a $\mathrm{CH}_{2} \mathrm{Cl}_{2} / \mathrm{CH}_{3} \mathrm{CN}$ mixed solvent. In contrast, the ammonium salt-type polymer exhibited only a random-coil conformation most likely because of the ionic character caused by the acidification. To compare the influence of the positions of the wheel and the ammonium moiety on the higher-order structure, the corresponding model polymer was synthesized and characterized by UV-Vis spectroscopy. A one-handed folded-helical conformation of the polymer was induced by a through-space chirality transfer from the optically active wheel component only when the wheel component was close to the polymer main chain.

Polymer Journal (2014) 46, 355-365; doi:10.1038/pj.2014.4; published online 12 March 2014

Keywords: crown ether; foldamer; helix; poly(m-phenylene diethynylene); side chain-type polyrotaxane

\section{INTRODUCTION}

Rotaxane has attracted much attention due to its potential applicability to crosslinked polymer materials and molecular devices based on its interlocked structure. ${ }^{1-4}$ Typical rotaxane-based devices include molecular switches that utilize stimuli-responsive isomerization of the relative position of the rotaxane components. ${ }^{5-9}$ However, the information per rotaxane molecule is limited and insufficient to generate macro-level functions; therefore, a method for amplifying the information output from rotaxane is required. ${ }^{10-12}$ Polyrotaxane $e^{13-20}$ can be considered an aggregate of rotaxane molecules because polymers can be regarded as aggregates of unit structures (Figure 1a). Of the many polyrotaxane types, the side chain-type polyrotaxane $\mathrm{C}^{21-26}$ is an intriguing class of polyrotaxanes that is characterized by the regular and controllable arrangement of rotaxane functions along the main chain. We have previously reported a few side chain-type polyrotaxanes prepared by the polymerization of optically active rotaxane monomers. ${ }^{27,28}$ Reversible positional control of the optically active wheel component of the pendant rotaxane moiety was conducted to control the higher-order structure of polyacetylene using the rotaxane switch. ${ }^{28}$ Interestingly, the polyacetylene helicity was efficiently controlled by the through-space chirality transfer from the movable wheel of the pendant rotaxane.

We also recently used such a rotaxane switch system to control the formation of a foldamer (Figures $1 \mathrm{~b}$ and $\mathrm{c}$ ). ${ }^{29} \mathrm{~A}$ foldamer is a dynamic helical polymer capable of undergoing a random coil-helical conformation transition. ${ }^{30-32}$ The system is represented by the $\pi$-conjugated oligo $(m$-phenylene ethynylene)s reported by Moore and co-workers. ${ }^{33,34}$ We have demonstrated the foldamer formation of poly( $m$-phenylene diethynylene) bearing a pendant rotaxane switch with an optically active wheel component. ${ }^{29}$ In a polar mixed solvent $\left(\mathrm{CH}_{2} \mathrm{Cl}_{2} / \mathrm{CH}_{3} \mathrm{CN}=1 / 1(\mathrm{v} / \mathrm{v})\right)$, poly- $(\boldsymbol{R})-1$ produced circular dichroism $(\mathrm{CD})$ and UV-Vis spectra that reflect the formation of a one-handed helical folded conformation on which the polymer main chain, as is typical of foldamers, consists of oligo ( $m$-phenylene ethynylene)s. This was the first report on the foldamer behavior of poly(m-phenylene diethynylene); however, the detailed properties of poly( $m$-phenylene diethynylene) as a foldamer and the effect of the side chain rotaxane structure were not described. To clarify the foldamer formation of poly( $m$-phenylene diethynylene), ${ }^{35-37}$ we have prepared poly( $m$-phenylene diethynylene)s tethering an achiral rotaxane side chain and a model [2] rotaxane. We describe the conditions and mechanism of the foldamer formation of poly ( $m$-phenylene diethynylene) in detail.

\section{EXPERIMENTAL PROCEDURE}

Materials and methods

All solvents were distilled or dried before use according to general purification procedures. Commercially available reagents were used without further 
a

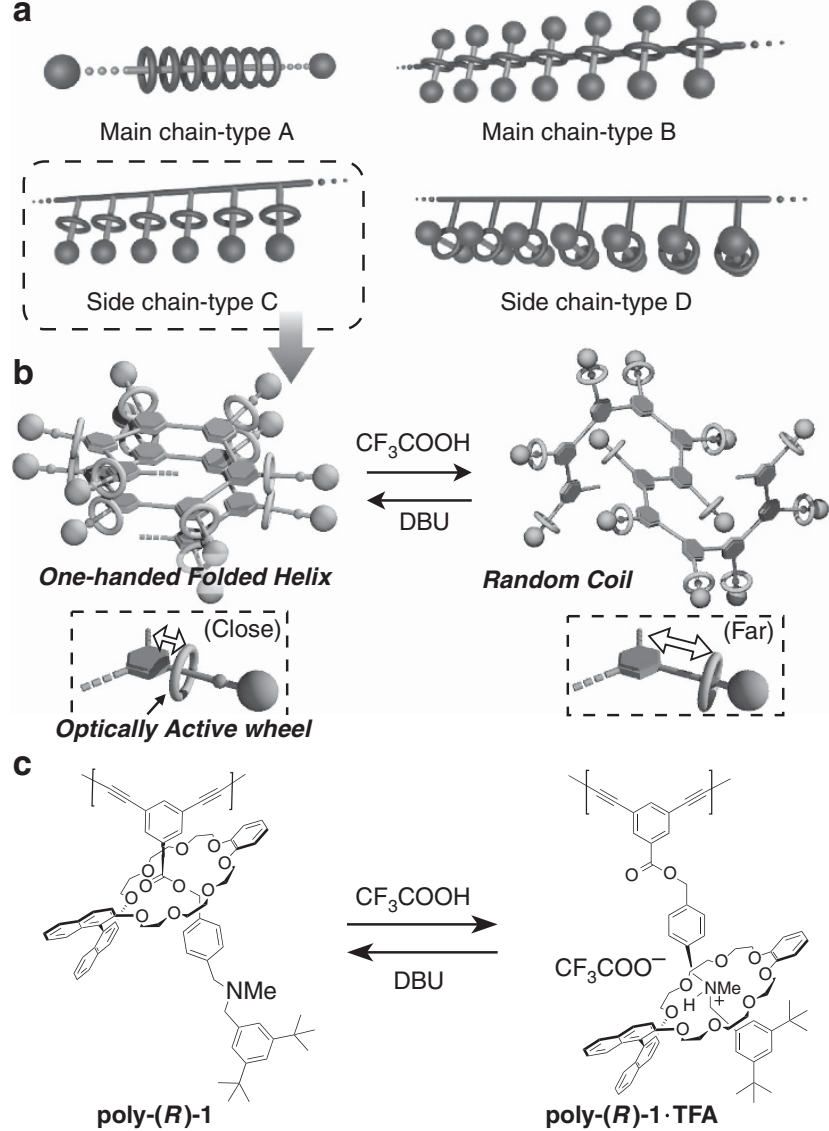

(DIC, $0.7 \mathrm{ml}, 4.7 \mathrm{mmol}$ ) to the solution at ambient temperature. After being stirred overnight, the mixture was poured into diethyl ether $(100 \mathrm{ml})$. The collected precipitates were purified by recrystallization from chloroform and 2-propanol to give $2(2.1 \mathrm{~g}, 2.1 \mathrm{mmol}, 85 \%)$ as a white solid.

m.p. $165.0-166.0{ }^{\circ} \mathrm{C} ;{ }^{1} \mathrm{H}$ NMR $\left(\mathrm{CDCl}_{3}, 298 \mathrm{~K}\right) \delta 8.11(\mathrm{~d}, J=1.4 \mathrm{~Hz}, 2 \mathrm{H})$, $7.77(\mathrm{t}, J=1.4 \mathrm{~Hz}, 1 \mathrm{H}), 7.60(\mathrm{br}, 2 \mathrm{H}), 7.37(\mathrm{~d}, J=8.0 \mathrm{~Hz}, 2 \mathrm{H}), \quad 7.24$ $(\mathrm{d}, J=8.0 \mathrm{~Hz}, 2 \mathrm{H}), 6.90-6.76(\mathrm{~m}, 11 \mathrm{H}), 5.27(\mathrm{~s}, 2 \mathrm{H}), 4.68-4.64(\mathrm{~m}, 2 \mathrm{H})$, $4.48-4.44(\mathrm{~m}, 2 \mathrm{H}), 4.10 \quad(\mathrm{~d}, J=4.4 \mathrm{~Hz}, 8 \mathrm{H}), 3.79-3.77(\mathrm{~m}, 8 \mathrm{H}), 3.48$ (s, 8H), 3.18 (s, 2H) and 2.16 (s, 6H) p.p.m.; ${ }^{13} \mathrm{C} \mathrm{NMR}\left(\mathrm{CDCl}_{3}, 298 \mathrm{~K}\right) \delta$ $164.5,147.3,139.4,138.3,136.5,133.1,131.9,131.3,130.6,130.6,129.6,128.1$, $126.5,123.1,121.6,112.5,81.3,79.3,70.6,70.1,68.0,66.4,52.6,52.1$ and 21.1 p.p.m.; IR $(\mathrm{KBr}) 3278\left(v_{\mathrm{C} \equiv \mathrm{C}-\mathrm{H} \text {, as }}\right), 2923\left(v_{\mathrm{C}-\mathrm{H} \text {, as }}\right), 2875\left(v_{\mathrm{C}-\mathrm{H}, \text { as }}\right), 1727$ $\left(v_{\mathrm{C}=\mathrm{O} \text {, as }}\right), 1507\left(v_{\mathrm{C}=\mathrm{C} \text {, as }}\right), 1217\left(v_{\mathrm{C}(=\mathrm{O}) \text {-O-C, as }}\right), 1055\left(v_{\mathrm{C}-\mathrm{O}-\mathrm{C} \text {, as }}\right), 842\left(v_{\mathrm{P}-\mathrm{F}, \text { as }}\right)$ and $558\left(v_{\mathrm{P}-\mathrm{F}, \mathrm{s}}\right) \mathrm{cm}^{-1}$; FAB-HR-MS calcd. for $\mathrm{C}_{52} \mathrm{H}_{58} \mathrm{NO}_{10}\left[\mathrm{M}-\mathrm{PF}_{6}\right]^{+}$ 856.4061, found 856.4036 .

Synthesis of rotaxane monomer 3. Paraformaldehyde ( $1.2 \mathrm{~g}, 40 \mathrm{mmol})$, sodium triacetoxyborohydride $(2.1 \mathrm{~g}, 10 \mathrm{mmol})$ and triethylamine $(5.5 \mathrm{ml}, 40 \mathrm{mmol})$ were added to a solution of $2(2.0 \mathrm{~g}, 2.0 \mathrm{mmol})$ in dry $\mathrm{N}$-methylpyrrolidone $(20 \mathrm{ml})$, and the suspension was subsequently heated to $70^{\circ} \mathrm{C}$ for $16 \mathrm{~h}$. The mixture was cooled to ambient temperature; $20 \mathrm{ml}$ of water was added to the mixture and the mixture was extracted three times with EtOAc $(30 \mathrm{ml})$. The combined organic layers were washed with water and brine, dried over $\mathrm{MgSO}_{4}$ and concentrated under reduced pressure. The residue was purified by short column chromatography (aluminum oxide, EtOAc) and recrystallized from chloroform and 2-propanol to give $3(1.3 \mathrm{~g}, 1.5 \mathrm{mmol}, 75 \%)$ as a white solid.

m.p. $123.8-125.2{ }^{\circ} \mathrm{C} ;{ }^{1} \mathrm{H} \mathrm{NMR}\left(\mathrm{CDCl}_{3}, 298 \mathrm{~K}\right) \delta 8.66(\mathrm{~d}, J=1.1 \mathrm{~Hz}, 2 \mathrm{H})$, $7.95(\mathrm{~d}, J=8.1 \mathrm{~Hz}, 2 \mathrm{H}), 7.57(\mathrm{~s}, 1 \mathrm{H}), 7.16(\mathrm{~d}, J=8.1 \mathrm{~Hz}, 2 \mathrm{H}), 6.92(\mathrm{~s}, 2 \mathrm{H})$ 6.86-6.74 (m, 9H), $5.86(\mathrm{~s}, 2 \mathrm{H}), 4.10-4.01(\mathrm{~m}, 8 \mathrm{H}), 3.67-3.65(\mathrm{~m}, 8 \mathrm{H}), 3.44$ $(\mathrm{s}, 2 \mathrm{H}), 3.37(\mathrm{~s}, 2 \mathrm{H}), 3.18-3.14(\mathrm{~m}, 4 \mathrm{H}), 3.01-2.98(\mathrm{~m}, 8 \mathrm{H}), 2.79(\mathrm{~s}, 2 \mathrm{H}), 2.28$ $(\mathrm{s}, 6 \mathrm{H})$ and 2.13 (s, 3H) p.p.m.; ${ }^{13} \mathrm{C} \mathrm{NMR}\left(\mathrm{CDCl}_{3}, 298 \mathrm{~K}\right) \delta 165.5,148.5$, $139.3,138.5,137.5,136.8,136.1,135.1,131.5,129.3,128.4,128.0,126.7,121.8$, $120.2,111.3,82.3,77.7,69.5,69.5,67.8,67.4,62.0,61.3$ and $42.2,21.2$ p.p.m. IR $(\mathrm{KBr}) 3284\left(v_{\mathrm{C} \equiv \mathrm{C}-\mathrm{H}, \text { as }}\right), 2917\left(v_{\mathrm{C}-\mathrm{H}, \text { as }}\right), 2872\left(v_{\mathrm{C}-\mathrm{H}, \text { as }}\right), 1719\left(v_{\mathrm{C}=\mathrm{O} \text {, as }}\right)$, $1505\left(v_{\mathrm{C}=\mathrm{C} \text {, as }}\right), 1218\left(v_{\mathrm{C}(=\mathrm{O})-\mathrm{O}-\mathrm{C} \text {, as }}\right)$ and $1051\left(v_{\mathrm{C}-\mathrm{O}-\mathrm{C} \text {, as }}\right) \mathrm{cm}^{-1}$; FAB-HR-MS calcd. for $\mathrm{C}_{53} \mathrm{H}_{60} \mathrm{NO}_{10}[\mathrm{M}+\mathrm{H}]^{+}$870.4217, found 870.4188.

of a helical foldamer and (c) switching behavior of poly-(R)-1. A full color version of this figure is available at Polymer Journal online.

purification unless otherwise noted. All of the reactions were performed under an inert atmosphere of argon. $\mathrm{SiO}_{2}$ column chromatography was performed using a Wakogel $\mathrm{C}-400 \mathrm{HG}$ chromatograph (Wako, Osaka, Japan). $\mathrm{Al}_{2} \mathrm{O}_{3}$ column chromatography was performed using standardized Merck Aluminum Oxide 90 (MSD, Darmstadt, Germany).

${ }^{1} \mathrm{H}(400 \mathrm{MHz})$ and ${ }^{13} \mathrm{C}(100 \mathrm{MHz})$ NMR spectra were recorded on a JEOL AL-400 spectrometer (JEOL, Tokyo, Japan) using $\mathrm{CDCl}_{3}$ as the solvent and tetramethylsilane as the internal standard. Samples were purified by repeated preparative gel permeation chromatography on a JAI LC-9204 system (JAIGEL-1H-40, JAI, Tokyo, Japan) using $\mathrm{CHCl}_{3}$ as the eluent. IR spectra were recorded on a JASCO FT/IR-230 spectrometer (JASCO, Tokyo, Japan). Melting points were measured on a Stuart Scientific SMP3 melting point apparatus (Bibby Scientific, Staffordshire, UK). UV-Vis spectra were collected on a JASCO V-550 UV-Vis spectrophotometer (JASCO). Molecular weights and their distributions were evaluated by size exclusion chromatography (SEC) on a JASCO HSS-1500 system (JASCO) equipped with consecutive linear polystyrene gel columns (TOSOH TSKgel G2000HXL and GMHXL, Tosoh, Tokyo, Japan) at $30^{\circ} \mathrm{C}$; the samples were eluted with $0.3 \% \mathrm{LiCl}$ at a flow rate of $0.85 \mathrm{ml} \mathrm{min}^{-1}$, and the instrument was calibrated using polystyrene standards. High-resolution mass spectra (HR-MS) data were collected at the National University Corporation, Tokyo Institute of Technology, Center for Advanced Materials Analysis.

\section{Syntheses}

Synthesis of rotaxane 2 . sec-ammonium-salt-containing benzyl alcohol ${ }^{38}$ $(1.0 \mathrm{~g}, 2.5 \mathrm{mmol})$ and dibenzo-24-crown-8-ether $(1.3 \mathrm{~g}, 2.9 \mathrm{mmol})$ were dissolved in $\mathrm{CH}_{2} \mathrm{Cl}_{2}(4.0 \mathrm{ml})$ to form a pseudo[2] rotaxane intermediate, followed by the addition of 3,5-diethynyl benzoic acid $(0.50 \mathrm{~g}, 2.9 \mathrm{mmol})$, tributylphosphane $(0.12 \mathrm{ml}, 0.50 \mathrm{mmol})$ and $N, N^{\prime}$-diisopropylcarbodiimide

Synthesis of rotaxane 3 TFA. Trifluoroacetic acid $(50 \mu \mathrm{l}, 0.60 \mathrm{mmol})$ was added dropwise to a solution of $\mathrm{N}$-methyl amine-type rotaxane $3(50 \mathrm{mg}$, $57 \mu \mathrm{mol})$ in $\mathrm{CH}_{2} \mathrm{Cl}_{2}(1.0 \mathrm{ml})$ at $0{ }^{\circ} \mathrm{C}$. After the mixture was stirred at room temperature for $30 \mathrm{~min}, 10 \mathrm{ml}$ of $\mathrm{CH}_{2} \mathrm{Cl}_{2}$ was added, and the solution was washed with water and brine. The organic layer was subsequently dried over $\mathrm{MgSO}_{4}$ and concentrated in vacuo. The titled 3•TFA (47 mg, $47 \mathrm{mmol}, 84 \%$ ) was obtained as a white solid and used without further purification.

m.p. 118.2-123.5 ${ }^{\circ} \mathrm{C} ;{ }^{1} \mathrm{H}$ NMR $\left(\mathrm{CDCl}_{3}, 298 \mathrm{~K}\right) \delta 8.08(\mathrm{~d}, J=1.2 \mathrm{~Hz} 2 \mathrm{H})$, $7.76(\mathrm{t}, J=1.2 \mathrm{~Hz}, 1 \mathrm{H}), 7.66(\mathrm{~d}, J=8.0 \mathrm{~Hz}, 2 \mathrm{H}), 7.20(\mathrm{~d}, J=8.0 \mathrm{~Hz}, 2 \mathrm{H}), 6.99$ (s, 2H), $6.94(\mathrm{~s}, 1 \mathrm{H}), 6.99-6.77(\mathrm{~m}, 8 \mathrm{H}), 5.27-5.23(\mathrm{~m}, 1 \mathrm{H}), 5.13(\mathrm{~d}, J=6.0$ $\mathrm{Hz}, 2 \mathrm{H}), 4.97-4.93(\mathrm{~m}, 1 \mathrm{H}), 4.58-4.53(\mathrm{~m}, 1 \mathrm{H}), 4.26-4.19(\mathrm{~m}, 1 \mathrm{H}), 4.19-4.11$ (m, 9H), 3.81-3.73 (m, 8H), 3.65-3.54 (m, 8H), $3.16(\mathrm{~s}, 2 \mathrm{H}), 2.95,2.93$, (s, 3H) and 2.21 (s, 6H), p.p.m.; ${ }^{13} \mathrm{C}$ NMR $\left(\mathrm{CDCl}_{3}, 298 \mathrm{~K}\right) \delta 164.6,147.4$, $147.3,139.4,138.5,137.1,133.4,131.9,131.2,130.8,130.2,129.7,129.1,128.2$, $123.0,121.2,121.2,111.8,111.7,81.5,79.2,71.5,71.3,70.4,70.3,68.2$, 68.0, 66.6, 60.6, 60.1, 39.3 and 21.3 p.p.m.; IR ( $\mathrm{KBr}) 3286\left(v_{\mathrm{C} \equiv \mathrm{C}-\mathrm{H} \text {, as }}\right), 2919$ $\left(v_{\mathrm{C}-\mathrm{H}, \text { as }}\right), 2875\left(v_{\mathrm{C}-\mathrm{H}, \text { as }}\right), 1724\left(v_{\mathrm{C}=\mathrm{O}, \text { as }}\right), 1692\left(v_{\mathrm{C}=\mathrm{O}, \text { as }}\right), 1505\left(v_{\mathrm{C}=\mathrm{C}, \text { as }}\right)$, $1212\left(v_{\mathrm{C}(=\mathrm{O})-\mathrm{O}-\mathrm{C}, \text { as }}\right), 1055\left(v_{\mathrm{C}-\mathrm{O}-\mathrm{C}, \text { as }}\right)$ and $769\left(v_{\mathrm{C}-\mathrm{F}}\right) \mathrm{cm}^{-1}$; ESI-TOF-HR-MS calcd. for $\mathrm{C}_{53} \mathrm{H}_{60} \mathrm{NO}_{10}\left[\mathrm{M}-\mathrm{CF}_{3} \mathrm{COO}\right]^{+}$870.4217, found 870.4222.

Polymerization of 3. In a Schlenk tube, a solution of rotaxane $3(0.17 \mathrm{~g}$, $0.20 \mathrm{mmol})$ and $\mathrm{CuCl}(\mathrm{I})(6.0 \mathrm{mg}, 60 \mu \mathrm{mol})$ in pyridine $(1.0 \mathrm{ml})$ was heated to $30^{\circ} \mathrm{C}$ as oxygen was bubbled through the solution. After the mixture was stirred for $3 \mathrm{~h}, 10 \mathrm{ml}$ of $\mathrm{CH}_{2} \mathrm{Cl}_{2}$ and $10 \% \mathrm{NH}_{4} \mathrm{Cl}$ aq. were added to the mixture, which was stirred overnight. The organic layer was washed with water and brine, dried over $\mathrm{MgSO}_{4}$ and concentrated under reduced pressure. The residue was dissolved in $\mathrm{CH}_{2} \mathrm{Cl}_{2}(5.0 \mathrm{ml})$ and poured into $n$-hexane $(50 \mathrm{ml})$ to form precipitates. The precipitates were collected by filtration and dried in vacuo. Poly-3 (0.14 g, $0.16 \mathrm{mmol}, 80 \%)$ was obtained as a white solid. 
$M_{\mathrm{w}} 91000 ; M_{\mathrm{n}} 44000 ;$ PDI 2.05 (estimated by SEC based on PSt standards, eluent DMF); $T_{\mathrm{d} 5} 302^{\circ} \mathrm{C} ; T_{\mathrm{d} 10} 313{ }^{\circ} \mathrm{C} ;{ }^{1} \mathrm{H}$ NMR $\left(\mathrm{CDCl}_{3}, 298 \mathrm{~K}\right) \delta 8.65(\mathrm{~s}, 2 \mathrm{H})$, $7.92(\mathrm{~d}, J=7.1 \mathrm{~Hz}, 2 \mathrm{H}), 7.55(\mathrm{~s}, 1 \mathrm{H}), 7.17(\mathrm{~d}, J=7.1 \mathrm{~Hz}, 2 \mathrm{H}), 6.93(\mathrm{~s}, 2 \mathrm{H})$, $6.85(\mathrm{~s}, 1 \mathrm{H}), 6.86-6.74(\mathrm{~m}, 8 \mathrm{H}), 5.89(\mathrm{~s}, 2 \mathrm{H}), 4.11-4.02(\mathrm{~m}, 8 \mathrm{H}), 3.67(\mathrm{br}, 8 \mathrm{H})$, $3.44(\mathrm{~s}, 2 \mathrm{H}), 3.37(\mathrm{~s}, 2 \mathrm{H}), 3.21(\mathrm{br}, 4 \mathrm{H}), 3.04(\mathrm{br}, 8 \mathrm{H}), 2.27(\mathrm{~s}, 6 \mathrm{H})$ and 2.13 (s, 3H) p.p.m.; ${ }^{13} \mathrm{C}$ NMR $\left(\mathrm{CDCl}_{3}, 298 \mathrm{~K}\right) \delta 165.2,148.3,139.3,139.0,137.5$, $137.5,136.3,135.8,131.8,129.4,128.4,128.0,126.7,121.6,120.4,111.4,80.2$, $74.4,69.6,67.8,67.5,62.0,61.3,42.2$ and 21.3 p.p.m.; IR (KBr) 2922 ( $\left.v_{\mathrm{C}-\mathrm{H}, \text { as }}\right)$, $2873\left(v_{\mathrm{C}-\mathrm{H}, \text { as }}\right), 1719\left(v_{\mathrm{C}=\mathrm{O}, \text { as }}\right), 1505\left(v_{\mathrm{C}=\mathrm{C} \text {, as }}\right), 1215\left(v_{\mathrm{C}(=\mathrm{O})-\mathrm{O}-\mathrm{C} \text {, as }}\right)$ and 1056 $\left(v_{\mathrm{C}-\mathrm{O}-\mathrm{C}, \text { as }}\right) \mathrm{cm}^{-1}$.

Acidification of poly-3. Trifluoroacetic acid $(0.1 \mathrm{ml}, 1.2 \mathrm{mmol})$ was added dropwise to a solution of poly-3 $(0.10 \mathrm{~g}, 0.12 \mathrm{mmol})$ in $\mathrm{CH}_{2} \mathrm{Cl}_{2}(2.0 \mathrm{ml})$ at $0{ }^{\circ} \mathrm{C}$. After the mixture was stirred at room temperature for $1 \mathrm{~h}, 10 \mathrm{ml}$ of $\mathrm{CH}_{2} \mathrm{Cl}_{2}$ was added; the solution was subsequently washed with water, dried over $\mathrm{MgSO}_{4}$ and finally concentrated in vacuo. Poly-3•TFA (98 mg, $1.0 \mathrm{mmol}$, $84 \%$ ) was obtained as a white solid.

${ }^{1} \mathrm{H}$ NMR $\left(\mathrm{CD}_{3} \mathrm{CN}, 333 \mathrm{~K}\right) \delta 8.12(\mathrm{~s}, 2 \mathrm{H}), 7.61(\mathrm{~s}, 1 \mathrm{H}), 7.59(\mathrm{br}, 2 \mathrm{H})$, 7.48 (br, 2H), 7.13 (s, 2H), 6.91 (s, 1H), 6.80 (br, 8H), 5.34 (s, 2H), 4.85-4.83 (m, 1H), 4.70-4.67 (m, 1H), 4.40-4.38 (m, 1H), 4.20-4.17 (s, 1H), 4.06-4.12 $(\mathrm{m}, 8 \mathrm{H}), 3.69-3.66(\mathrm{~m}, 8 \mathrm{H}), 3.40(\mathrm{br}, 8 \mathrm{H}), 2.77(\mathrm{~s}, 3 \mathrm{H})$ and $2.18(\mathrm{~s}, 6 \mathrm{H})$ p.p.m.; IR $(\mathrm{KBr}) 2921\left(v_{\mathrm{C}-\mathrm{H}, \text { as }}\right), 2882\left(v_{\mathrm{C}-\mathrm{H}, \text { as }}\right), 1733\left(v_{\mathrm{C}=\mathrm{O} \text {, as }}\right), 1505\left(v_{\mathrm{C}=\mathrm{C} \text {, as }}\right)$, $1206\left(v_{\mathrm{C}(=\mathrm{O}) \text {-O-C, as }}\right), 1055\left(v_{\mathrm{C}-\mathrm{O}-\mathrm{C}, \text { as }}\right)$ and $704\left(v_{\mathrm{C}-\mathrm{F}}\right) \mathrm{cm}^{-1}$.

Synthesis of rotaxane 4. Under inert atmosphere, $\mathrm{PdCl}_{2}\left(\mathrm{PPh}_{3}\right)_{2}(11 \mathrm{mg}$, $15 \mu \mathrm{mol}), \mathrm{CuI}(2.9 \mathrm{mg}, 15 \mu \mathrm{mol})$ and diisopropylamine $(0.14 \mathrm{ml}, 1.0 \mathrm{mmol})$ were added to a solution of rotaxane $3(0.44 \mathrm{~g}, 0.50 \mathrm{mmol})$ and (iodoethynyl)benzene $(0.27 \mathrm{~g}, 1.2 \mathrm{mmol})$ in THF $(8.0 \mathrm{ml})$. After the mixture was stirred for $15 \mathrm{~h}$ at room temperature, $\mathrm{CH}_{2} \mathrm{Cl}_{2}$ was added. The organic mixture was washed with $1 \mathrm{M} \mathrm{HCl}$ aq., water, sat. $\mathrm{NaHCO}_{3}$ aq. and brine. The organic layer was dried over $\mathrm{MgSO}_{4}$ and concentrated under reduced pressure. The residue was purified by column chromatography $\left(\mathrm{Al}_{2} \mathrm{O}_{3}, n\right.$-hexane/ethyl acetate $=2 / 1$, triethylamine $1.0 \%)$ to give rotaxane $4(0.22 \mathrm{~g}, 0.20 \mathrm{mmol}, 41 \%)$ as a yellow solid.

m.p. 82.4-83.6 ${ }^{\circ} \mathrm{C} ;{ }^{1} \mathrm{H}$ NMR $\left(400 \mathrm{MHz}, \mathrm{CDCl}_{3}, 298 \mathrm{~K}\right) \delta 8.69$ (s, 2H), 7.94 $(\mathrm{d}, J=7.8 \mathrm{~Hz}, 2 \mathrm{H}), 7.63(\mathrm{~s}, 1 \mathrm{H}), 7.50(\mathrm{~d}, J=6.5 \mathrm{~Hz}, 4 \mathrm{H}), 7.38-7.34(\mathrm{~m}, 6 \mathrm{H})$, $7.18(\mathrm{~d}, J=7.8 \mathrm{~Hz}, 2 \mathrm{H}), 6.93-6.76(\mathrm{~m}, 11 \mathrm{H}), 5.88(\mathrm{~s}, 2 \mathrm{H}), 4.13-4.06(\mathrm{~m}, 8 \mathrm{H})$, $3.68(\mathrm{~m}, 8 \mathrm{H}), 3.46(\mathrm{~s}, 2 \mathrm{H}), 3.37(\mathrm{~s}, 2 \mathrm{H}), 3.18(\mathrm{~m}, 4 \mathrm{H}), 3.02(\mathrm{~m}, 4 \mathrm{H}), 2.28$ (s, 6H) and 2.14 (s, 3H) p.p.m.; ${ }^{13} \mathrm{C}$ NMR $\left(100 \mathrm{MHz}, \mathrm{CDCl}_{3}, 298 \mathrm{~K}\right) \delta 148.5$, $139.5,139.1,137.7,136.4,135.9,132.7,129.5,129.4,128.5,128.2,126.8,121.8$, $120.5,111.5,80.3,74.7,74.0,69.7,68.0,62.2,61.4$ and 21.4 p.p.m.; IR (KBr) 2874, 1714, 1591, 1505, 1451, 1252 and 738, $688 \mathrm{~cm}^{-1}$; FAB-HR-MS calcd. for $\mathrm{C}_{69} \mathrm{H}_{67} \mathrm{NO}_{10}[\mathrm{M}+\mathrm{H}]^{+} 1070.4843$, found 1070.4852 .

Polymerization of 5. In accordance with the previously described procedure for the synthesis of poly-3, $5(84 \mathrm{mg}, 0.20 \mathrm{mmol})$ and $\mathrm{CuCl}(\mathrm{I})(6.0 \mathrm{mg}$, $60 \mu \mathrm{mol})$ were used and stirred for $3 \mathrm{~h}$. Poly-5 (62 mg, $0.15 \mathrm{mmol}, 73 \%)$ was obtained as a pale yellow solid.

$M_{\mathrm{n}} 17000$ (estimated by ${ }^{1} \mathrm{H}$ NMR); ${ }^{1} \mathrm{H}$ NMR $\left(\mathrm{CDCl}_{3} 298 \mathrm{~K}\right) \delta 8.18$ (d, $J=1.5 \mathrm{~Hz}, 2 \mathrm{H}), 7.78(\mathrm{~s}, 2 \mathrm{H}), 7.40(\mathrm{~s}, 4 \mathrm{H}), 6.96(\mathrm{~s}, 2 \mathrm{H}), 6.87(\mathrm{~s}, 1 \mathrm{H})$, $5.35(\mathrm{~s}, 2 \mathrm{H}), 3.52(\mathrm{~s}, 2 \mathrm{H}), 3.45(\mathrm{~s}, 2 \mathrm{H}), 2.29(\mathrm{~s}, 6 \mathrm{H})$ and $2.18(\mathrm{~s}, 3 \mathrm{H})$ p.p.m.; IR $(\mathrm{KBr}) 2917\left(v_{\mathrm{C}-\mathrm{H}}\right.$, as $), 2835\left(v_{\mathrm{C}-\mathrm{H}, \text { as }}\right), 1727\left(v_{\mathrm{C}=\mathrm{O}, \text { as }}\right)$ and 1244 $\left(v_{\mathrm{C}(=\mathrm{O})-\mathrm{O}-\mathrm{C}, \text { as }}\right) \mathrm{cm}^{-1}$.

Polymerization of 6 . In accordance with the previously described procedure for the synthesis of poly-3, $6(0.17 \mathrm{~g}, 0.20 \mathrm{mmol})$ and $\mathrm{CuCl}(\mathrm{I})(6.0 \mathrm{mg}$, $60 \mu \mathrm{mol})$ were used and stirred for $3 \mathrm{~h}$. Poly- $6(0.15 \mathrm{~g}, 1.8 \mathrm{mmol}, 88 \%)$ was obtained as a white solid.

$M_{\mathrm{n}} 16000 ; M_{\mathrm{w}} 29000$; PDI 1.54 (estimated by SEC based on PSt standards, eluent DMF); $T_{\mathrm{d} 5} 213^{\circ} \mathrm{C} ; T_{\mathrm{d} 10} 235^{\circ} \mathrm{C} ;{ }^{1} \mathrm{H}$ NMR $\left(298 \mathrm{~K}, \mathrm{CDCl}_{3}\right): \delta 8.17(\mathrm{~d}$, $J=7.8 \mathrm{~Hz}, 2 \mathrm{H}), 8.11(\mathrm{~s}, 1 \mathrm{H}), 7.50(\mathrm{~s}, 1 \mathrm{H}), 7.47(\mathrm{~s}, 2 \mathrm{H}), 7.12(\mathrm{~d}, J=7.8 \mathrm{~Hz}$, $2 \mathrm{H}), 7.05(\mathrm{~s}, 1 \mathrm{H}), 6.87-6.84(\mathrm{~m}, 8 \mathrm{H}), 6.00(\mathrm{~s}, 2 \mathrm{H}), 4.06(\mathrm{br}, 8 \mathrm{H}), 3.71-3.66$ $(\mathrm{m}, 8 \mathrm{H}), 3.42(\mathrm{~s}, 2 \mathrm{H}), 3.31(\mathrm{~s}, 2 \mathrm{H}), 3.23-3.22(\mathrm{~m}, 4 \mathrm{H}), 2.88-2.87(\mathrm{~m}, 4 \mathrm{H}), 2.18$ (s, 6H), 2.10 (s, 3H) p.p.m.; ${ }^{13} \mathrm{C}$ NMR $\left(\mathrm{CDCl}_{3} 298 \mathrm{~K}\right) \delta 165.2,148.3,139.3$, $139.0,137.5,136.9,136.3,135.8,131.9,129.4,128.4,128.0,126.7,121.5,120.4$, $111.4,80.2,76.7,74.4,69.6,69.6,67.9,67.5,62.0,61.3,42.2$ and 21.3 p.p.m.;
IR ( $\mathrm{KBr}) 2918\left(v_{\mathrm{C}-\mathrm{H}, \text { as }}\right), 2874\left(v_{\mathrm{C}-\mathrm{H}, \text { as }}\right), 1718\left(v_{\mathrm{C}=\mathrm{O} \text {, as }}\right), 1507\left(v_{\mathrm{C}=\mathrm{C} \text {, as }}\right)$, $1212\left(v_{\mathrm{C}(=\mathrm{O})-\mathrm{O}-\mathrm{C}, \text { as }}\right)$ and 1057 ( $\left.v_{\mathrm{C}-\mathrm{O}-\mathrm{C}, \text { as }}\right) \mathrm{cm}^{-1}$.

Polymerization of $(\boldsymbol{R})-7$. In accordance with the previously described procedure for the synthesis of poly-3, $(\boldsymbol{R})-7(0.12 \mathrm{~g}, 0.11 \mathrm{mmol})$ and $\mathrm{CuCl}(\mathrm{I})$ $(3.0 \mathrm{mg}, 30 \mu \mathrm{mol})$ were used. Poly-(R)-7 (98 mg, $90 \mu \mathrm{mol}, 82 \%)$ was obtained as a pale yellow solid.

$M_{\mathrm{n}} 31000 ; M_{\mathrm{w}} 70000$; PDI 2.23 (estimated by SEC based on PSt standards, eluent DMF); $[\alpha]_{\mathrm{D}}^{25}:+153^{\circ}(c=0.10$, THF $) ;{ }^{1} \mathrm{H}$ NMR $\left(\mathrm{CDCl}_{3} 298 \mathrm{~K}\right) \delta$ 7.92-7.88 (m. 3H), 7.78-7.75 (m, 2H), $7.57(\mathrm{~s}, 1 \mathrm{H}), 7.48(\mathrm{~s}, 1 \mathrm{H}), 7.40(\mathrm{~s}, 2 \mathrm{H})$, 7.34-7.16 (m, 11H), 6.91-6.64 (m, 6H), $5.37(\mathrm{~s}, 2 \mathrm{H}), 4.30-4.27(\mathrm{~m}, 1 \mathrm{H})$, 4.06-4.04 (m, 1H), 3.95-3.88 (m, 3H), 3.75-2.78 (m, 23H), $2.02(\mathrm{~s}, 3 \mathrm{H}), 1.32$ (s, 18H) p.p.m.; IR ( $\mathrm{KBr}) 2950\left(v_{\mathrm{C}-\mathrm{H}, \text { as }}\right), 2869\left(v_{\mathrm{C}-\mathrm{H}, \text { as }}\right), 1728\left(v_{\mathrm{C}=\mathrm{O}, \text { as }}\right), 1511$ $\left(v_{\mathrm{C}=\mathrm{C}, \text { as }}\right), 1214\left(v_{\mathrm{C}(=\mathrm{O})-\mathrm{O}-\mathrm{C}, \text { as }}\right)$ and $1066\left(v_{\mathrm{C}-\mathrm{O}-\mathrm{C}, \text { as }}\right) \mathrm{cm}^{-1}$.

\section{RESULTS AND DISCUSSION}

\section{Design and synthesis of monomers}

The rotaxane switch system we utilized in previous investigations consisted of an optically active crown ether and a tert-amine group containing an axle component. ${ }^{28,29}$ The positional switching of the crown ether in the rotaxane was driven by the protonation and deprotonation of the tert-amine (that is, the tert-ammonium) moiety. In general, the hydrogen bonding between the tert-ammonium salt and the crown ether is too weak to be detected by spectroscopic analyses; however, intramolecular hydrogen bonding in a rotaxane skeleton is well stabilized to catch the crown ether on the tertammonium moiety. ${ }^{8,9}$ In this study, we designed such a tert-amine/ ammonium salt-type rotaxane with an achiral crown ether (dibenzo24-crown-8-ether (DB24C8)) and a polymerizable end-cap group. Oligo( $m$-phenylene ethynylene)s, which are typical foldamers, are generally prepared by stepwise synthesis via Sonogashira coupling conditions to avoid dimerization as a side reaction.

To obtain polyrotaxane with a sufficiently high molecular weight and without decomposition of the rotaxane skeleton, we used oxidative coupling polymerization because a homocoupling polymerization system is expected to generate a high-molecularweight polymer under mild conditions. Before synthesizing poly( $m$-phenylene diethynylene), ${ }^{35-37}$ we calculated the energyminimized structure using a model oligomer, oligo(benzyl 3,5diethynylbenzoate), as shown in Figure 2. The structure we obtained was a folded-helical conformation that consists of a $5_{1}$ helix.

A 1,3-diethynylbenzene group was introduced as the polymerizable group on an end-cap group via ester bonding. As shown in Scheme 1, a pseudorotaxane complex of $\mathrm{DB} 24 \mathrm{C} 8$ and the axle precursor were terminated by tributylphosphane-catalyzed condensation with
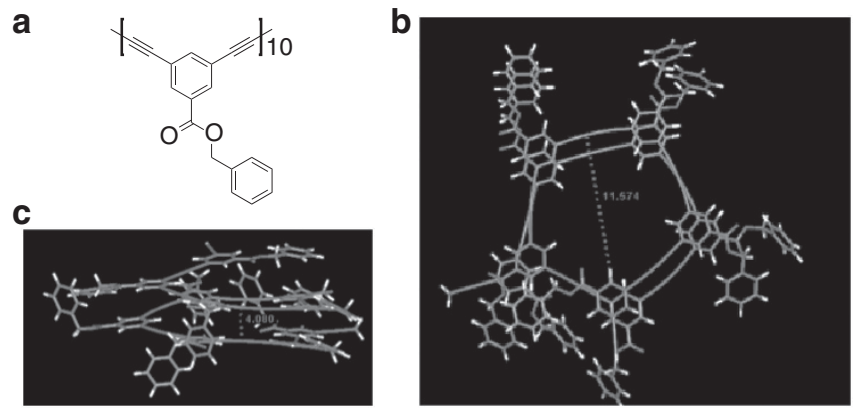

Figure 2 An energy-minimized structure of benzyl 3,5-diethynylbenzoate oligomer as a model of poly ( $m$-phenylene diethynylene), as calculated by OPLS 2005. (a) Chemical structure, (b) top view and (c) side view. A full color version of this figure is available at Polymer Journal online. 

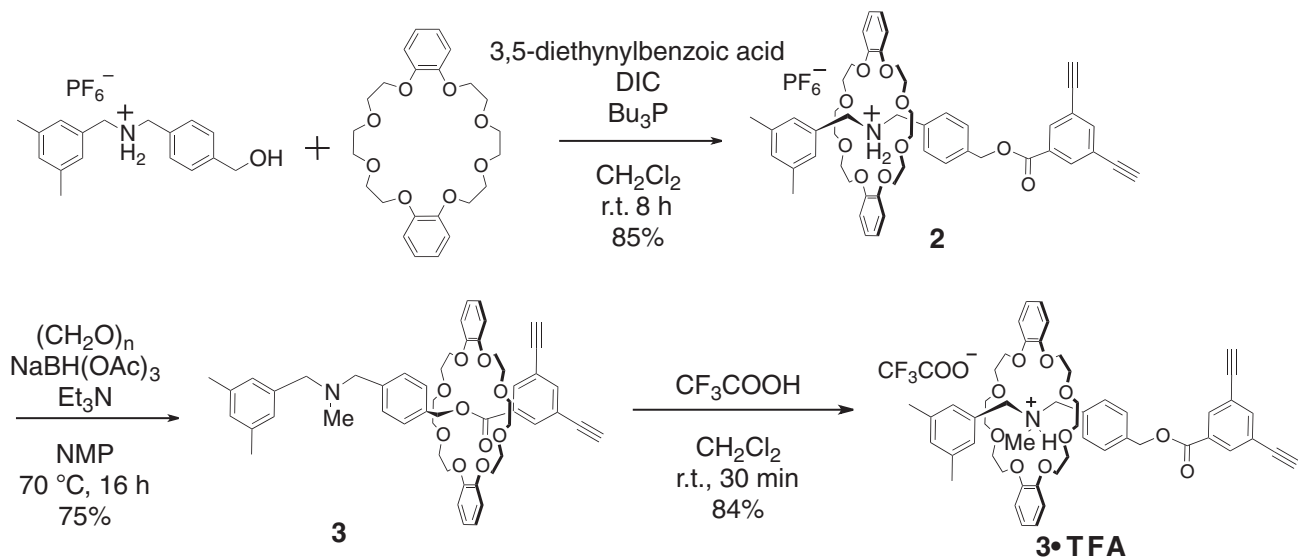

Scheme 1 . Synthesis of $\mathbf{3}$ and $\mathbf{3} \bullet$ TFA.

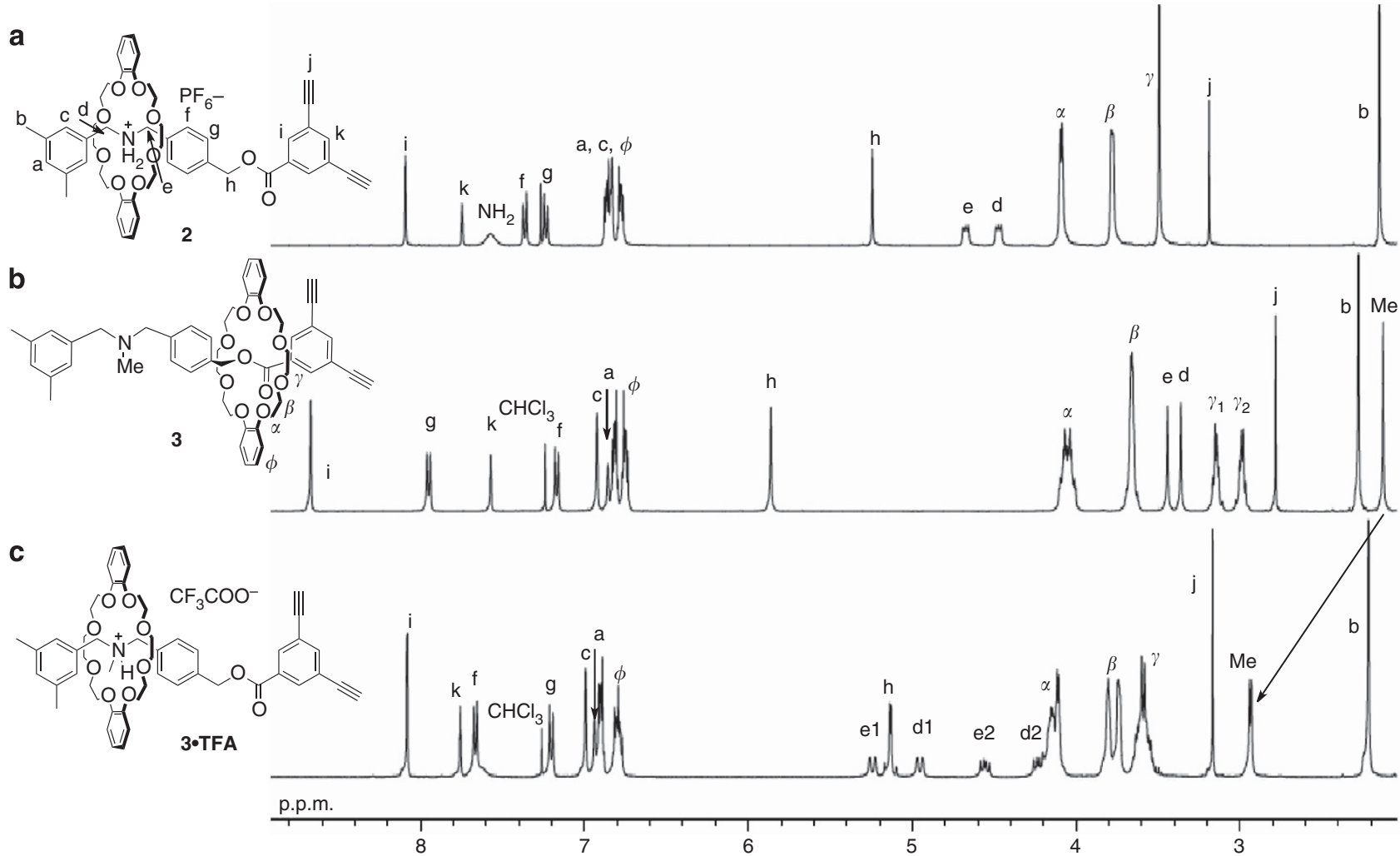

Figure $3{ }^{1} \mathrm{H}$ NMR spectra of (a) sec-ammonium salt-type rotaxane 2 , (b) tert-amine-type rotaxane 3 and (c) tert-ammonium salt-type rotaxane $3 \cdot$ TFA $\left(400 \mathrm{MHz}, 298 \mathrm{~K}\right.$, in $\left.\mathrm{CDCl}_{3}\right)$.

3,5-diethynyl benzoic acid to obtain sec-ammonium salt-type rotaxane $2 .^{38}$ Subsequent $N$-methylation ${ }^{8,9}$ of rotaxane 2 produced tert-amine-type rotaxane monomer 3 . The protonation of 3 with trifluoroacetic acid (TFA) gave the corresponding tert-ammonium salt-type rotaxane $3 \bullet$ TFA.

The ${ }^{1} \mathrm{H}$ NMR spectra of these monomers supported the structure as shown in Figure 3. The wheel positions of the tert-amine-type rotaxane 3 and the tert-ammonium salt-type 3•TFA were evaluated on the basis of the spectra of sec-ammonium salt-type rotaxane 2 , for which the relative position of the wheel on the axle component was determined by crystal structural analysis. ${ }^{39,40}$ The $N$-methyl signals $(\mathrm{Me})$ of 3 and 3•TFA were observed at 2.2 p.p.m. and 2.9 p.p.m., respectively; the large downfield shift associated with the TFA treatment was due not only to the protonation of the nitrogen atom but also to the formation of hydrogen bonds with the wheel component. The signals of the terminal methyl protons $\left(\mathrm{H}_{\mathrm{b}}\right)$ and ethynyl protons $\left(\mathrm{H}_{\mathrm{j}}\right)$ were complementarily shifted after protonation to support the positional change of the wheel component. In addition, the $O$-benzylic proton signal $\left(\mathrm{H}_{\mathrm{h}}\right)$ was substantially shifted after the protonation, which suggests hydrogen bonding between the $O$-benzylic protons and the oxygen atoms on the closed crown ether in the tert-amine-type rotaxane 3 . These characteristic chemical shifts, that is, the positional change of the wheel component from around the O-benzyl ester group (3) 

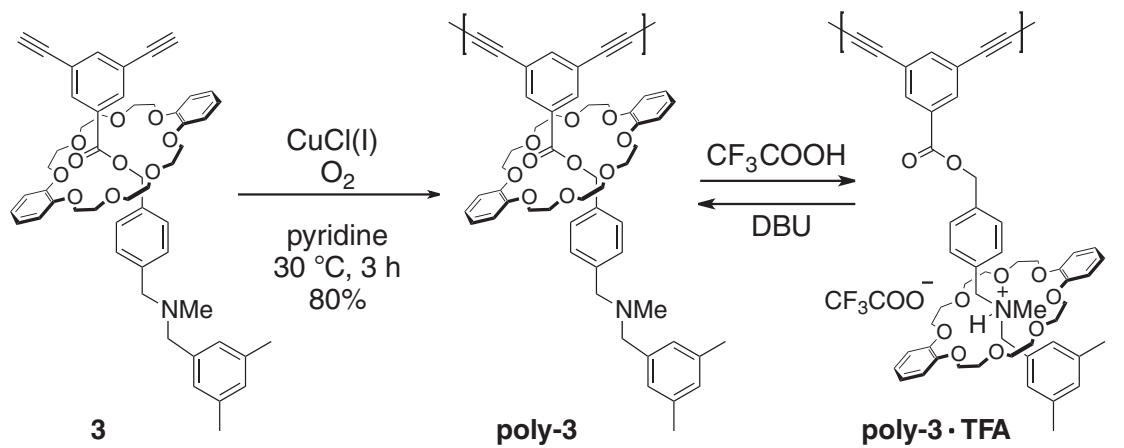

Scheme 2. Synthesis of poly-3 and poly-3•TFA.

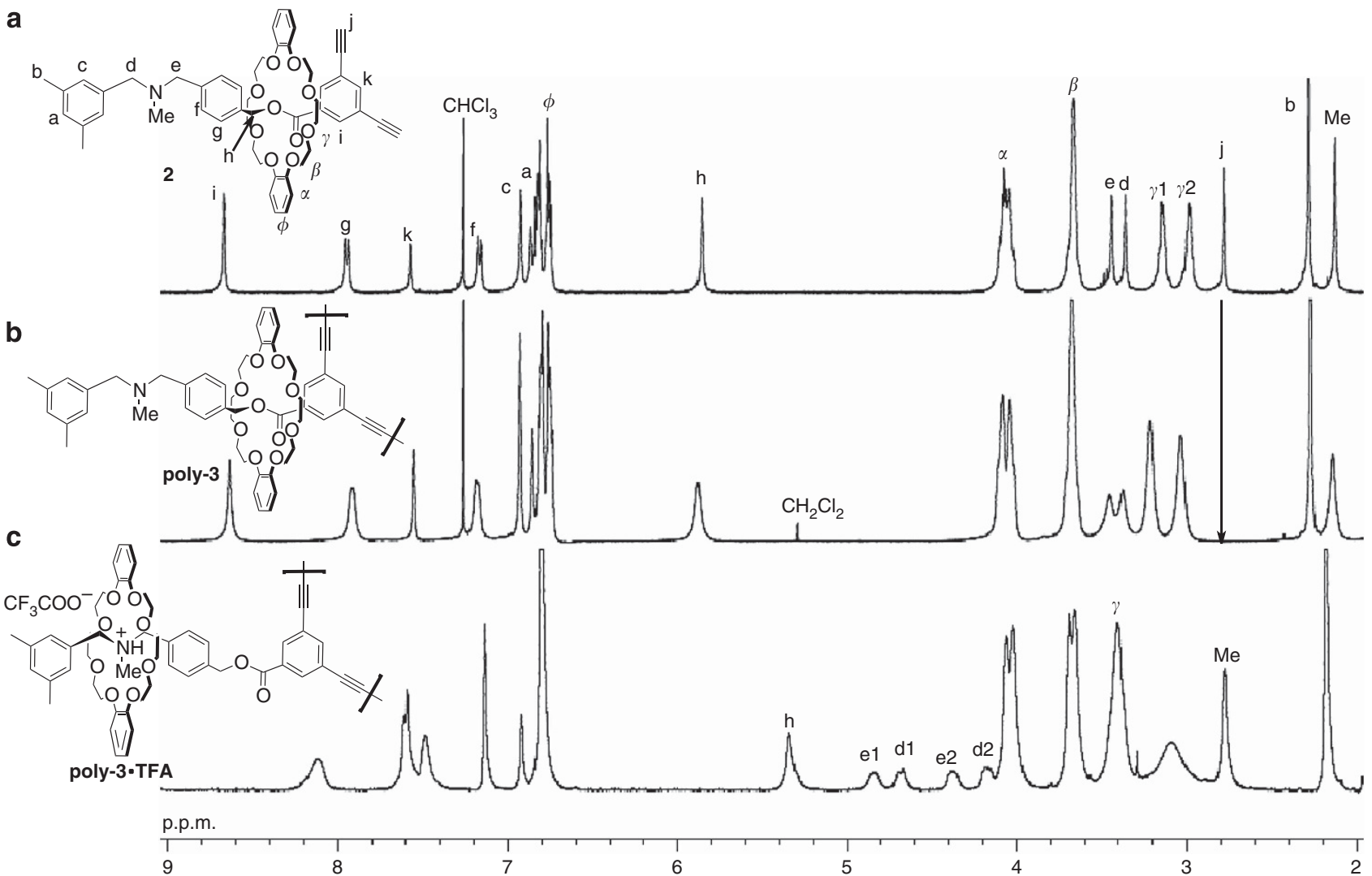

Figure $4{ }^{1} \mathrm{H}$ NMR spectra of (a) 3 (in $\mathrm{CDCl}_{3}$ ), (b) poly-3 (in $\mathrm{CDCl}_{3}$ ) and (c) poly-3•TFA (in $\mathrm{CD}_{3} \mathrm{CN}$ ) $(400 \mathrm{MHz}, 298 \mathrm{~K}$ ).

to the tert-ammonium salt moiety (3•TFA) on the axle, agree with those reported previously. 8,9 The treatment of 3•TFA with 1,8-diazabicyclo[5.4.0] undec-7-ene (DBU) gave an identical spectrum of the initial tert-amine-type rotaxane $3 .{ }^{8,9}$

\section{Polymerization}

Copper(I)-mediated oxidative coupling polymerizations of rotaxane monomers 2, 3 and 3•TFA were performed according to Hay's method. ${ }^{41,42}$ We successfully prepared poly-3 in $80 \%$ yield from the tert-amine-type monomer 3 under optimized conditions using $\mathrm{CuCl}(\mathrm{I})(30 \mathrm{~mol} \%)$ in pyridine with $\mathrm{O}_{2}$ bubbling for $3 \mathrm{~h}$ (Scheme 2).

However, we could not obtain polymers from ammonium salt-type monomers 2 and 3•TFA (When the polymerization of monomer 2•TFA was carried out at $60^{\circ} \mathrm{C}$, a brown gel was obtained. The ${ }^{1} \mathrm{H}$ NMR spectrum was coincident with the corresponding polymer well, so that the partial crosslinking reaction at the 1,4-diphenyl-1,3butadiyne structure was considered as the reason for the gelation. However, polymer was not obtained from monomer 3•TFA, and the oligomer and monomer were recovered. Presumably, the polymerization is probably inhibited by protonating the copper acetylide by the presence of ammonium group. As mentioned in our previous report, the kinetic acidity of the sec-ammonium group in crown ether-type rotaxane is very low to neutralize under general conditions, so that such a protonation of the generated copper acetylide could not be considered in the polymerization of monomer 2•TFA.). The ${ }^{1} \mathrm{H}$ NMR spectrum of poly-3 was consistent with that of monomer $\mathbf{3}$ except for the disappearance of the ethynyl proton signal $\left(\mathrm{H}_{\mathrm{j}}\right.$, Figures $4 \mathrm{a}$ and $\mathrm{b}$ ), which suggests that the rotaxane structure is maintained in the polymer. Moreover, IR spectra (Supplementary Figure S9; Supplementary Information) and SEC analysis showed that successive 

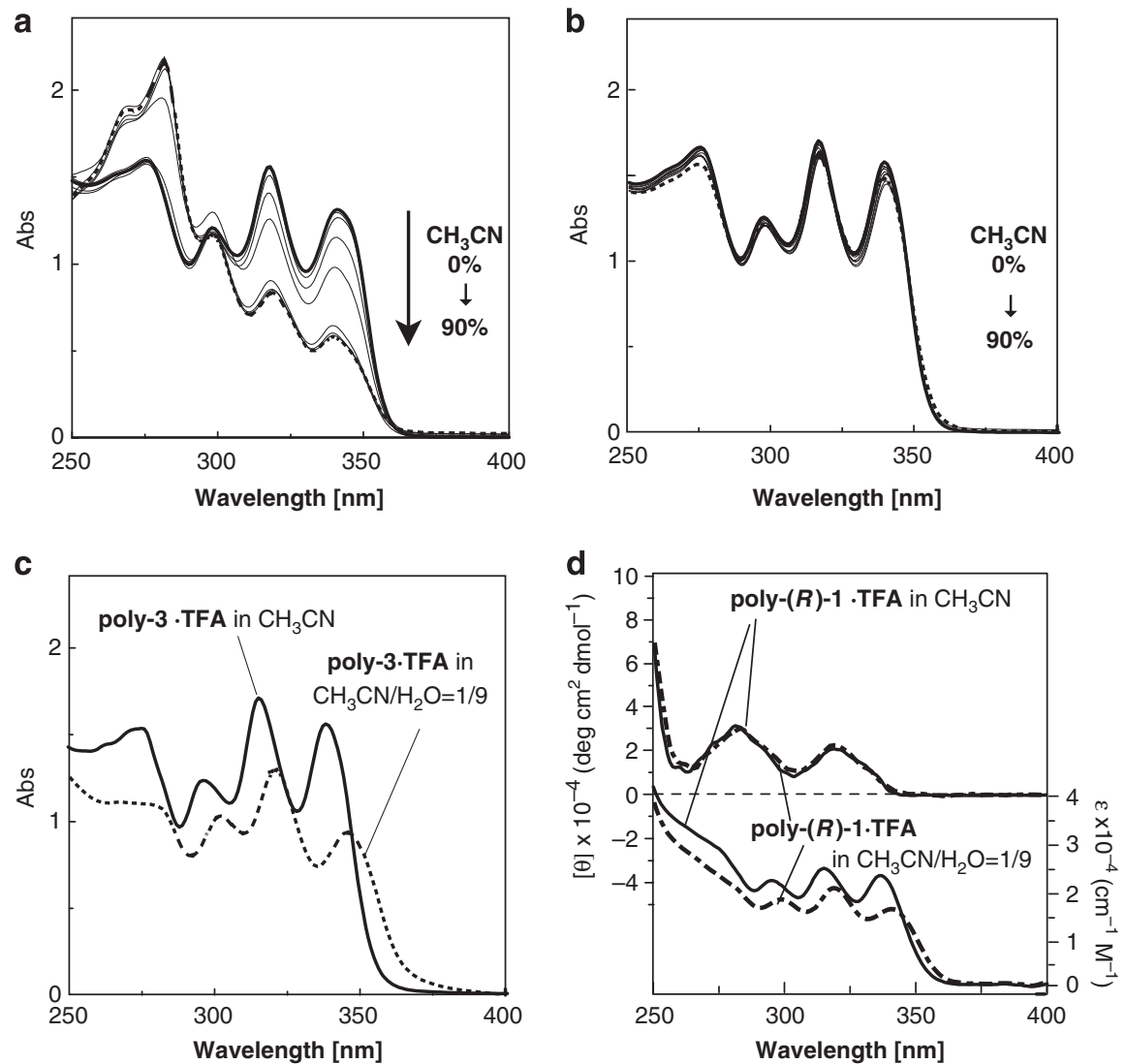

Figure 5 UV-Vis spectra of (a) poly-3 (solid line: in $\mathrm{CH}_{2} \mathrm{Cl}_{2}$, dashed line: in $\mathrm{CH}_{2} \mathrm{Cl}_{2} / \mathrm{CH}_{3} \mathrm{CN}=2 / 3$ ), (b) poly-3•TFA (solid line: in $\mathrm{CH}_{2} \mathrm{Cl}_{2}$, dashed line: in $\mathrm{CH}_{2} \mathrm{Cl}_{2} / \mathrm{CH}_{3} \mathrm{CN}=1 / 9$ ) and (c) poly-3•TFA (solid line: in $\mathrm{CH}_{3} \mathrm{CN}$, dashed line: in $\mathrm{CH}_{3} \mathrm{CN} / \mathrm{H}_{2} \mathrm{O}=1 / 9$ ). $\mathrm{CD}$ and UV-Vis spectra of (d) poly-(R)-1•TFA (solid line: in $\mathrm{CH}_{3} \mathrm{CN}$, dashed line: in $\left.\mathrm{CH}_{3} \mathrm{CN} / \mathrm{H}_{2} \mathrm{O}=1 / 9\right)(0.05 \mathrm{~mm}, 293 \mathrm{~K})$.

polymerization generated high-molecular weight poly-3 $\left(M_{\mathrm{n}} 44000\right.$, $M_{\mathrm{w}} 91000$, PDI 2.05, PSt standards). The estimated molecular weight showed that the obtained poly-3 was at least a 40 -mer of the rotaxane. (The molecular weight of poly-5 was also evaluated by SLS analysis (in DMF, $0.3 \% \mathrm{LiCl}$ ), and the obtained value was consistent with that estimated by SEC. Poly-3 could not be analyzed by SLS because of the low solubility in DMF; however, the value obtained by SEC is reasonable.) We prepared the tert-ammonium salttype polymer (poly-3•TFA) by treating poly-3 with excess $\mathrm{TFA}^{28,29}$ and determined the structure using ${ }^{1} \mathrm{H}$ NMR (Figure $4 \mathrm{c}$ ). The changes in the ${ }^{1} \mathrm{H}$ NMR spectrum upon the conversion of poly-3 to poly-3•TFA were the same as those observed with nonpolymer systems. These clear chemical shifts unambiguously suggest the positional change of the wheel component on the side chain and showed that the wheel component exists at the tertammonium group in poly-3•TFA and around the O-benzyl ester moiety in poly-3.

Higher-order structural analysis of poly- 3 and poly-3•TFA Poly ( $m$-phenylene diethynylene) is expected to behave as a foldamer. Its higher-order structure was evaluated by UV-Vis spectroscopic analysis in various ratios of mixed $\mathrm{CH}_{2} \mathrm{Cl}_{2} / \mathrm{CH}_{3} \mathrm{CN}$ solvent (Figure 5).

Both poly-3 and poly-3•TFA showed strong absorptions in the $350-300 \mathrm{~nm}$ region, depending on the 1,4-diphenyl-1,3-butadiyne unit. When the percentage of $\mathrm{CH}_{3} \mathrm{CN}$ was increased, the spectrum of poly-3 changed gradually; and in a mixed solvent of $\left(\mathrm{CH}_{2} \mathrm{Cl}_{2} /\right.$ $\left.\mathrm{CH}_{3} \mathrm{CN}=2 / 3(v / v)\right)$, a remarkable hypochromic effect with a red shift of the main chain absorption was maximized. The hypochromic effect is a powerful indicator of the oriented chromophores commonly observed in DNA, RNA and other polymers, and is sensitive to the distance between chromophores and their relative orientations. ${ }^{43,44}$

Therefore, this result revealed that the 1,4-diphenyl-1,3-butadiyne units were arranged by $\pi-\pi$ stacking interactions, ${ }^{44}$ which strongly suggest the formation of a folded-coil-shaped conformation of poly-3 (that is, a helix) in a mixed solvent. Moore and co-workers ${ }^{33,34}$ reported a similar effect of the solvent composition on the conformation of linear phenylene ethynylene oligomers, and Tobe et al. ${ }^{45}$ reported that the cyclic oligomer consisting of $m$-diethynylbenzenes strongly aggregates in a polar solvent, accompanied by a hypochromic shift in the absorption spectrum. We were at first concerned with the steric hindrance between the wheel components located near the polymer backbone, which inhibits the formation of a folded conformation. However, the flexible structure of rotaxane made the formation possible, and the solvophobic effect of $\mathrm{CH}_{3} \mathrm{CN}$ effectively stabilized the structure. In contrast, the spectrum of poly-3•TFA in these solvent systems did not show any remarkable change. Thus, the results showed that poly-3•TFA is incapable of assuming a folded conformation in these solvent systems, most likely because of the electrostatic repulsion between the ammonium moieties on the side chains. To further understand the interaction of poly-3•TFA with its solvent, we measured the ${ }^{1} \mathrm{H}$ NMR and UV-Vis spectra of poly3•TFA in a polar solvent (Figure $5 \mathrm{c}$ and Supplementary Figure S10; Supplementary Information $)^{46,47}$ In a mixed solvent $\left(\mathrm{CH}_{3} \mathrm{CN} /\right.$ $\left.\mathrm{H}_{2} \mathrm{O}=1 / 9(v / v)\right)$, poly-3•TFA showed a hypochromic effect similar 

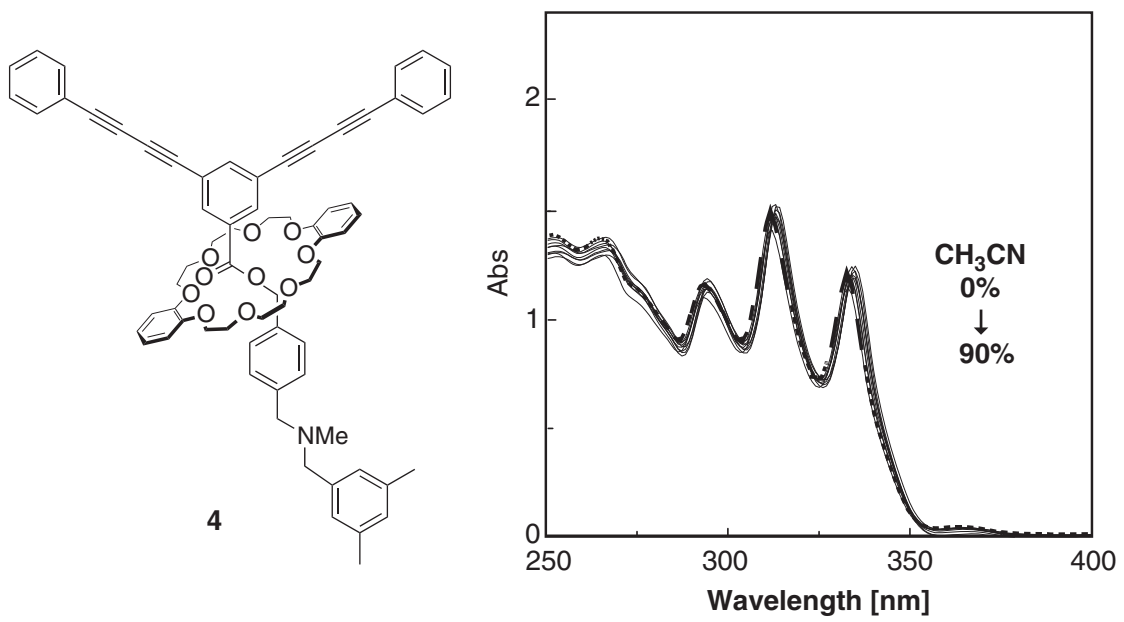

Figure 6 Structure of 4 and UV-Vis spectra of 4 (solid line: in $\mathrm{CH}_{2} \mathrm{Cl}_{2}$, dashed line: in $\left.\mathrm{CH}_{2} \mathrm{Cl}_{2} / \mathrm{CH}_{3} \mathrm{CN}=1 / 9\right)(0.05 \mathrm{~mm}, 293 \mathrm{~K}$ ).

a

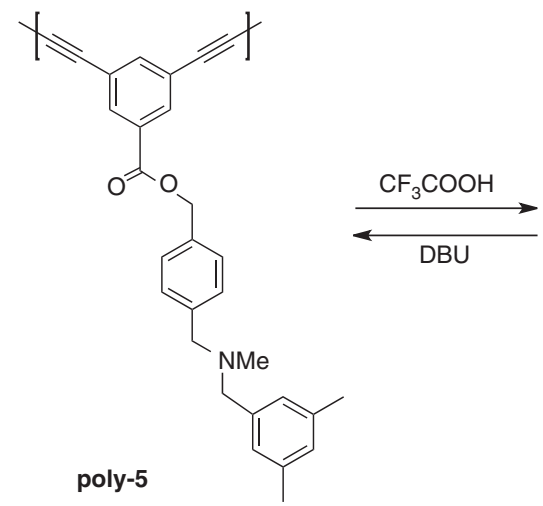

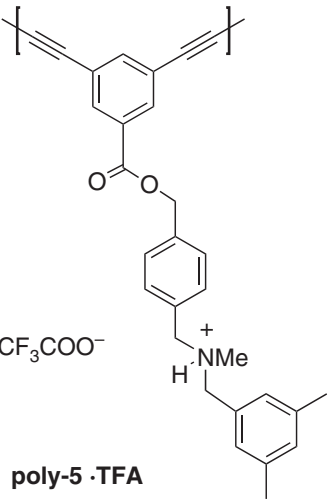

c

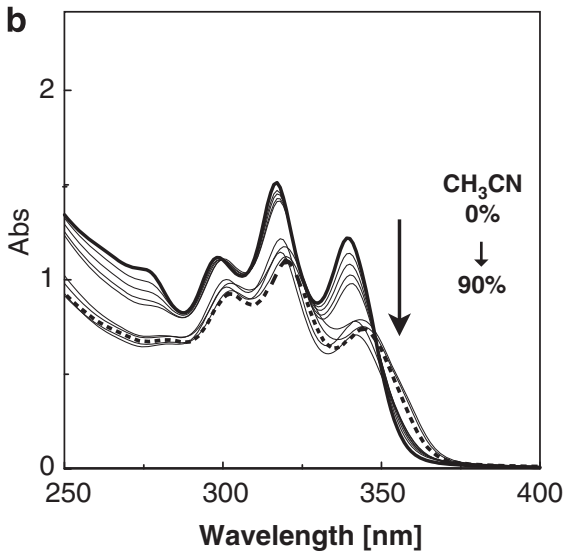

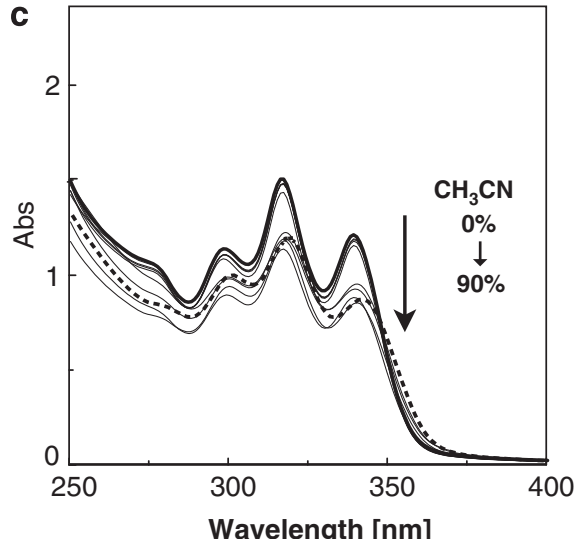

Figure 7 (a) Switching behavior of poly-5, (b) UV-Vis spectra of poly-5 (solid line: in $\mathrm{CH}_{2} \mathrm{Cl}_{2}$, dashed line: in $\mathrm{CH}_{2} \mathrm{Cl}_{2} / \mathrm{CH}_{3} \mathrm{CN}=1 / 9$ ) and (c) UV-Vis spectra of poly-5•TFA (solid line: in $\mathrm{CH}_{2} \mathrm{Cl}_{2}$, dashed line: in $\left.\mathrm{CH}_{2} \mathrm{Cl}_{2} / \mathrm{CH}_{3} \mathrm{CN}=1 / 9\right)(0.05 \mathrm{~mm}, 293 \mathrm{~K}$ ).

to that of poly-3 in $\mathrm{CH}_{2} \mathrm{Cl}_{2} / \mathrm{CH}_{3} \mathrm{CN}=2 / 3(v / v)$, suggesting the formation of a folded conformation (that is, a helix).

Next, we measured the CD and UV-Vis spectra of poly-(R)-1•TFA (Figure 1) in the $\mathrm{CH}_{3} \mathrm{CN} / \mathrm{H}_{2} \mathrm{O}$ mixed solvent (Figure 5d). In $\mathrm{CH}_{3} \mathrm{CN}$, the spectra of poly- $(R)-1 \bullet$ TFA were similar to those in $\mathrm{CH}_{2} \mathrm{Cl}_{2}$. In $\mathrm{CH}_{3} \mathrm{CN} / \mathrm{H}_{2} \mathrm{O}=1 / 9(v / v)$, poly- $(\boldsymbol{R})-1 \bullet T F A$ showed a hypochromic effect similar to that of poly- $(\boldsymbol{R})-\mathbf{1}$ in $\mathrm{CH}_{2} \mathrm{Cl}_{2} / \mathrm{CH}_{3} \mathrm{CN}=2 / 3(v / v)$. This result corresponds to the formation of a folded-coil-shaped conformation, that is, a helical foldamer.
However, poly- $(\boldsymbol{R})$-1•TFA should form a racemic helical conformation in the mixed solvent because the $\mathrm{CD}$ spectrum was similar to that in $\mathrm{CH}_{3} \mathrm{CN}$ (Figure 5d). This is consistent with the position of the optically active wheel component (that is, the asymmetric field) being far from the main chain.

These results show that poly ( $m$-phenylene diethynylene) is a foldamer of which the conformation can be controlled by the solvent. The rotaxane switch has the key role in determining the helix sense, while at the same time drastically changing 

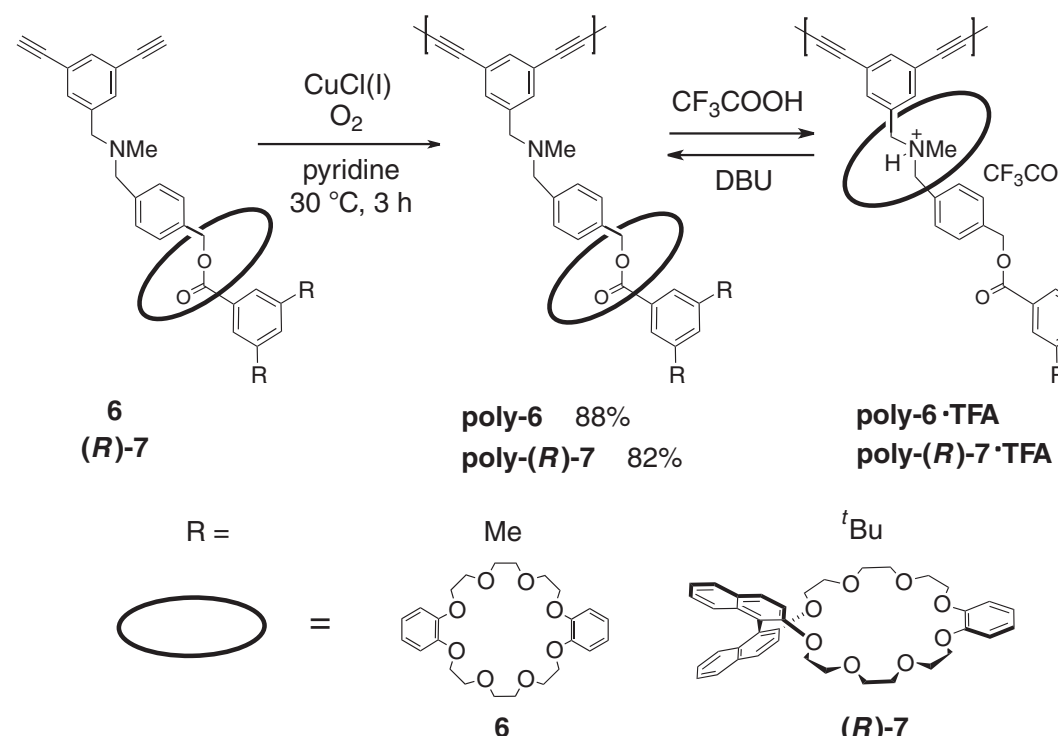

poly- $(R)-7 \cdot$ TFA

${ }^{t} \mathrm{Bu}$

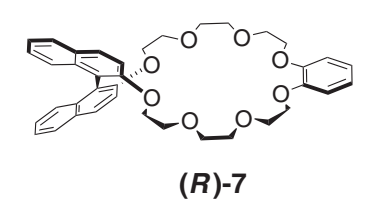

Scheme 3 Synthesis of poly-6, poly-6•TFA, poly- $(R)-7$ and poly-(R)-7•TFA.

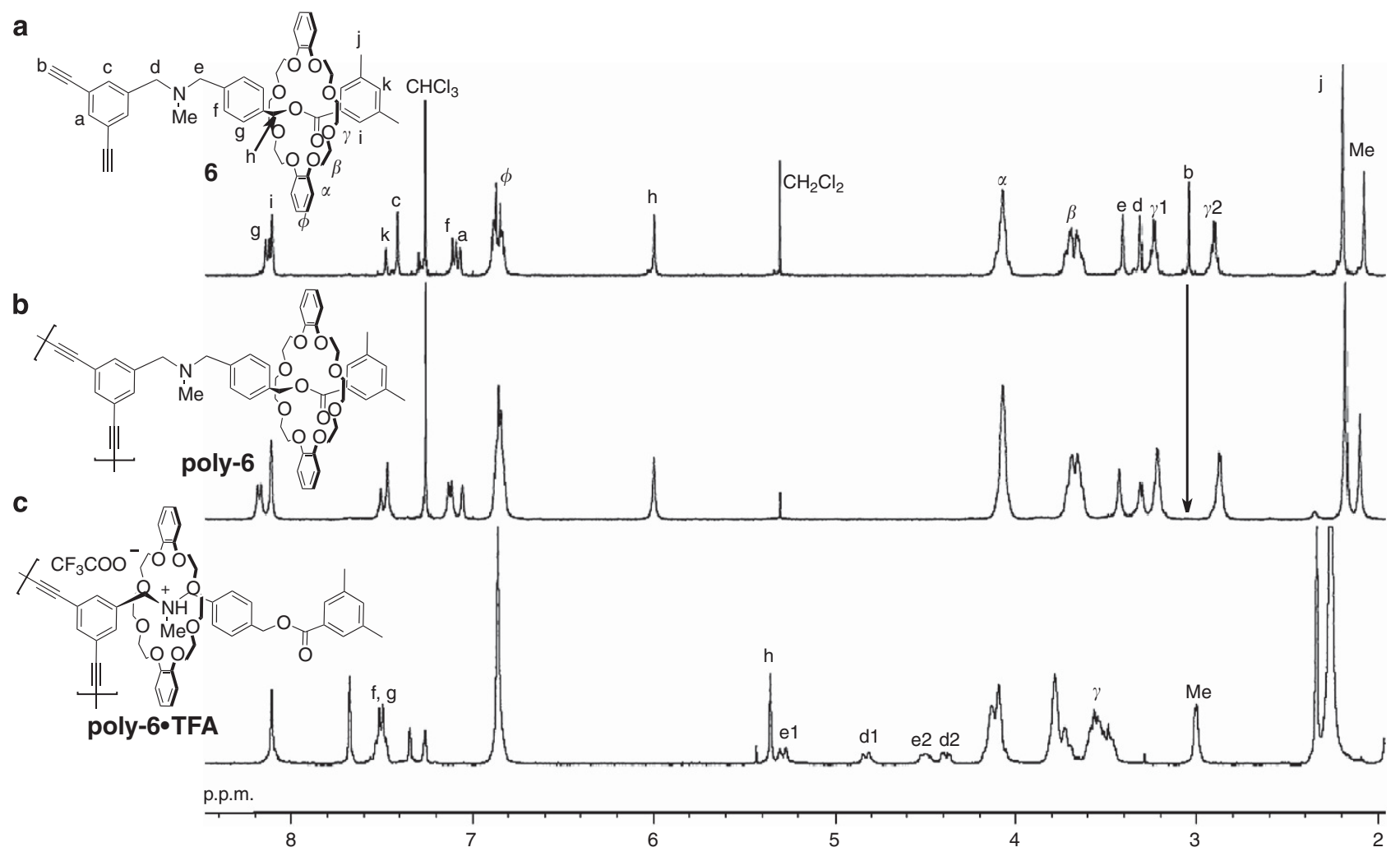

Figure $8{ }^{1} \mathrm{H}$ NMR spectra of (a) 6 (in $\mathrm{CDCl}_{3}$ ), (b) poly-6 (in $\mathrm{CDCl}_{3}$ ) and (c) poly-6•TFA (in $\mathrm{CD}_{3} \mathrm{CN}$ ) $(400 \mathrm{MHz}, 298 \mathrm{~K}$ ).

the interaction of the main chain with the solvent, as shown in Figure 1.

To confirm that the folded-coil-shaped conformation was induced by the intramolecular $\pi-\pi$ interactions of the poly $(m$-phenylene diethynylene) backbone, we investigated the concentration effect of poly-3 (Supplementary Figure S29; Supplementary Information). At a low concentration $(0.005 \mathrm{~mm})$, poly-3 showed a hypochromic effect similar to that shown at a high concentration $(0.05 \mathrm{~mm})$, which suggests $\pi-\pi$ interactions of the polymer backbone. Next, we prepared model rotaxane $\mathbf{4}$ and measured its UV-Vis spectrum (Figure 6). There were no remarkable changes in the UV-Vis spectrum of $\mathbf{4}$ in any of the investigated solvent systems. Thus, intermolecular $\pi-\pi$ interactions of the 1,4-diphenyl-1,3butadiyne moiety are impossible at this concentration. These results showed that the hypochromic effect of poly-3 was due to the intramolecular $\pi-\pi$ interactions specific to the polymer 
a
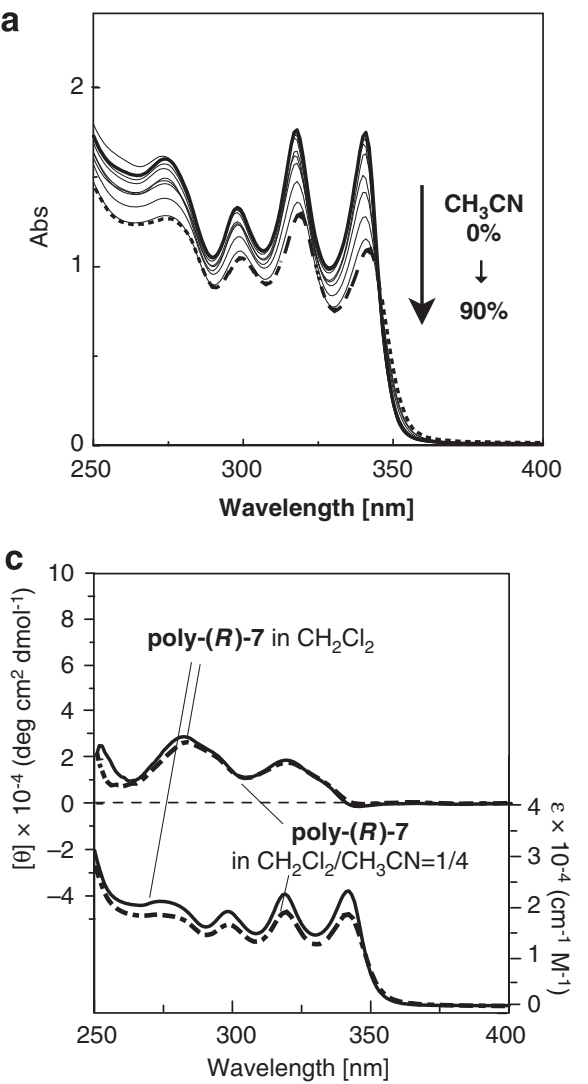

b
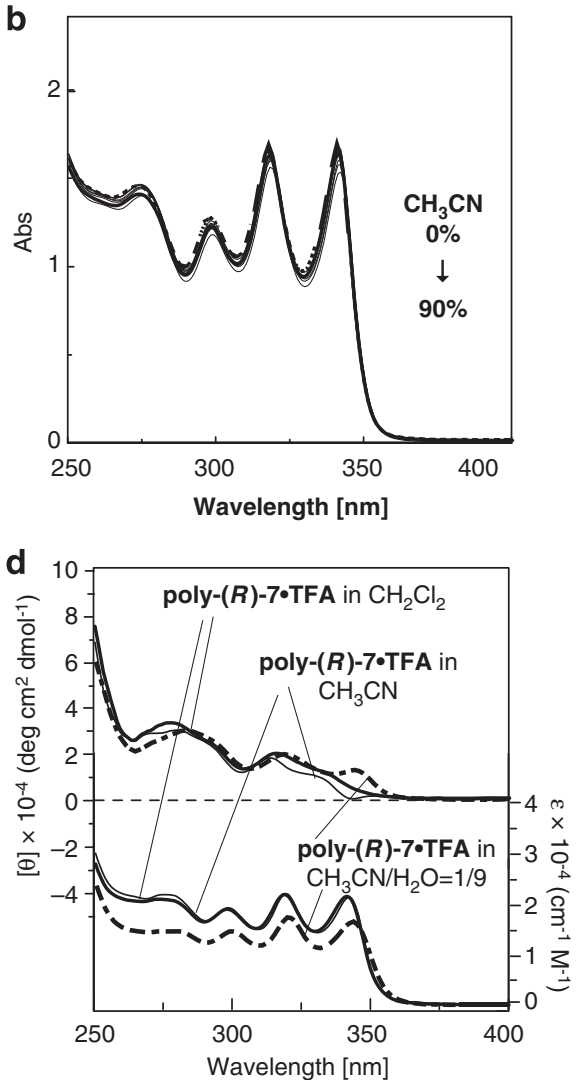

Figure 9 UV-Vis spectra of (a) poly-6 (solid line: in $\mathrm{CH}_{2} \mathrm{Cl}_{2}$, dashed line: in $\mathrm{CH}_{2} \mathrm{Cl}_{2} / \mathrm{CH}_{3} \mathrm{CN}=1 / 9$ ) and (b) poly-6•TFA (solid line: in $\mathrm{CH}_{2} \mathrm{Cl}_{2}$, dashed line: in $\left.\mathrm{CH}_{2} \mathrm{Cl}_{2} / \mathrm{CH}_{3} \mathrm{CN}=1 / 9\right)$. CD and UV-Vis spectra of (c) poly-(R)-7 (solid line: in $\mathrm{CH}_{2} \mathrm{Cl}_{2}$, dashed line: in $\left.\mathrm{CH}_{2} \mathrm{Cl}_{2} / \mathrm{CH}_{3} \mathrm{CN}=1 / 4\right)$ and $(\mathbf{d})$ poly-(R)-7•TFA (bold solid line: in $\mathrm{CH}_{2} \mathrm{Cl}_{2}$, solid line: in $\mathrm{CH}_{3} \mathrm{CN}$, dashed line: in $\left.\mathrm{CH}_{3} \mathrm{CN} / \mathrm{H}_{2} \mathrm{O}=1 / 9\right)(0.05 \mathrm{~mm}, 293 \mathrm{~K})$.

backbone, which become possible when poly-3 assumes a folded conformation.

To clarify the influence of the rotaxane structure on the higherorder structure, we synthesized poly-5 from monomer 5, which corresponded to the axle component. Poly-5 was prepared in the same way as poly-3 in $83 \%$ yield. The ${ }^{1} \mathrm{H}$ NMR and IR spectra clearly showed the structure of poly-5 $\left(M_{\mathrm{n}} 17000\right)$.

The UV-Vis spectra of poly-5 and poly-5•TFA are shown in Figures $7 \mathrm{~b}$ and $\mathrm{c}$. In a good solvent $\left(\mathrm{CH}_{2} \mathrm{Cl}_{2}\right)$, both spectra showed strong absorptions around the main chain absorption region. However, both polymers showed a weak hypochromic effect similar to that of poly-3 in $\mathrm{CH}_{2} \mathrm{Cl}_{2} / \mathrm{CH}_{3} \mathrm{CN}=1 / 9(\mathrm{v} / \mathrm{v})$, which suggests the formation of the folded helical conformation. The significant conformational difference between poly-5•TFA and poly-3•TFA is most likely caused by the difference in their solvent affinity, which results from the difference in the cation charge state of the ammonium moiety in poly-3•TFA (delocalized by the crown ether wheel) and in poly-5•TFA (localized).

Synthesis and structural analysis of poly-6 and poly- $(R)-7$

To compare the influence of the positions of the wheel and the ammonium moiety on the higher-order structure, we synthesized poly-6 and poly- $(R)-7$ from rotaxane monomers 6 and $(R)-7$, which have an ammonium moiety located near the polymer main chain; this arrangement differs from that of rotaxane monomer $\mathbf{3}$ and $(\boldsymbol{R})-\mathbf{1}$. The polymerizations of $\mathbf{6}$ and $(\boldsymbol{R})-\mathbf{7}$ were performed under the same optimized conditions used for the preparation of $\mathbf{3}$ and gave poly- $\mathbf{6}$ and poly-(R)-7 in high yields (poly-6: $88 \%$; poly-(R)-: 7 82\%) (Scheme 3).

The ${ }^{1} \mathrm{H}$ NMR and IR spectra along with the SEC results (poly-6 $M_{\mathrm{n}}$ $16000, M_{\mathrm{w}} 29000$, PDI 1.54; poly-(R)-7 $M_{\mathrm{n}} 31000, M_{\mathrm{w}} 70000$, PDI 2.23 , PSt standards) showed the successful polymerization of 6 and (R)-7. We also confirmed the switching ability of the polymers using an acid treatment; a positional change of the wheel component resulted from treating poly-6 with TFA (Figures $8 \mathrm{~b}$ and $\mathrm{c}$ ). The $N$-methyl signal of poly-6 was shifted substantially downfield, and the $O$-benzylic proton signal was clearly shifted upfield. These changes were similar to those observed for poly-3, which suggests that the positional change of the wheel component on the axle occurred. After the DBU treatment of poly-6•TFA, the same ${ }^{1} \mathrm{H}$ NMR spectrum was obtained as that obtained with the initial poly-6. The UV-Vis spectra of poly-6 and poly-6•TFA are shown in Figures 9a and b. In a good solvent $\left(\mathrm{CH}_{2} \mathrm{Cl}_{2}\right)$, both poly-6 and poly-6•TFA showed strong absorptions on the basis of the main chain. In a mixed solvent $\left(\mathrm{CH}_{2} \mathrm{Cl}_{2} / \mathrm{CH}_{3} \mathrm{CN}=1 / 9(v / v)\right)$, poly-6 showed a weak hypochromic effect similar to that of poly-3, which suggests the formation of the folded conformation of poly-6 (that is, a helix). Bruce et al. ${ }^{48}$ have reported that the electron-withdrawing substituents on oligo $(m-$ phenylene ethynylene) stabilize the folding structure of the main chain. On the basis of their results, the weak hypochromic effect of poly- 6 is the result of the drawback of $\pi-\pi$ interactions, most likely due to an electron donation from the methylamine substituent making the folded structure unstable. In addition, the spectra of poly-6•TFA in $\mathrm{CH}_{2} \mathrm{Cl}_{2} / \mathrm{CH}_{3} \mathrm{CN}$ solvent systems did not change enough to signify the higher-order structural change. 
Next, we measured the CD and UV-Vis spectra of poly- $(\boldsymbol{R})-7$ and poly- $(R)-7 \bullet$ TFA (Figures $9 \mathrm{c}$ and d). In a good solvent $\left(\mathrm{CH}_{2} \mathrm{Cl}_{2}\right)$, both poly- $(R)-7$ and poly- $(R)-7 \bullet T F A$ showed the typical UV-Vis absorption for the main chain. In a mixed solvent $\left(\mathrm{CH}_{2} \mathrm{Cl}_{2} /\right.$ $\left.\mathrm{CH}_{3} \mathrm{CN}=1 / 4(v / v)\right)$, poly- $(\boldsymbol{R})-7$ showed a weak hypochromic effect that suggests the folded conformation. However, significant changes in the Cotton effect were not observed in the CD spectrum, as the optically active wheel component was located at a position far from the main chain. Similar to poly-6•TFA, poly(R)-7•TFA did not take on the folded helical conformation in $\mathrm{CH}_{3} \mathrm{CN}$ even though the wheel component was located near the main chain. Thus the CD spectra in a higher polar solvent were measured to find a strong solvophobic effect. In fact, poly- $(\boldsymbol{R})-$ 7•TFA showed a weak hypochromic effect that suggests the folded conformation of poly- $(\boldsymbol{R})-7$ TFA (that is, the helix) in a mixed solvent $\left(\mathrm{CH}_{3} \mathrm{CN} / \mathrm{H}_{2} \mathrm{O}=1 / 9(v / v)\right)$. However, the $\mathrm{CD}$ spectrum of poly- $(R)-7 \bullet T F A$ in the same solvent did not change to indicate the one-handed helical conformation induced by the through-space chirality transfer from the optically active wheel component. The efficiency of the through-space chirality transfer is most likely related to the distance between the main chain and the optically active wheel, and that distance is controlled by hydrogen bonding in the rotaxane system. The polar solvent system weakens the hydrogen bonding between the components by solvating the ammonium moiety. As a result, the probability of the wheel component approaching the main chain is reduced compared with that of the poly- $(\boldsymbol{R})-\mathbf{1}$ in the lower polar solvent system. ${ }^{49}$ Therefore, to achieve the through-space chirality transfer from the wheel component of the rotaxane side chain, it is effective to use a solvent system with the polarity as low as possible. Thus, to control the folding structure of poly( $m$-phenylene diethynylene) efficiently, the component arrangement of the rotaxane moieties of poly-(R)-1 and poly-3 is more favorable than the component arrangement of the rotaxane moieties of poly- 6 and poly- $(R)-7$.

\section{CONCLUSIONS}

We have used detailed spectroscopic characterization to study the conditions and mechanism of the foldamer formation of poly ( $m$-phenylene diethynylene)s possessing a mobile componenttethering rotaxane moiety in the side chain. The foldamer formation was controlled by the positional switching of the wheel component of the side chain rotaxane caused by the treatment of the amine moiety with TFA and DBU. On the basis of the UV-Vis spectroscopic analysis, the structure of the initial tert-amine-type polymer obtained by the polymerization of tert-amine-type rotaxane monomers was determined to be a folded-coil-shaped structure stabilized by intramolecular $\pi-\pi$ interactions of the main chain in a mixed solvent $\left(\mathrm{CH}_{2} \mathrm{Cl}_{2} / \mathrm{CH}_{3} \mathrm{CN}\right)$. Protonation of the tert-amine moiety on the axle of the side chain rotaxane, that is, the wheel component away from the main chain, showed that the structure was a random coil that resulted from the change in the solvent affinity. This structural change was also supported by a comparison of the UV-Vis spectra of a model of the corresponding rotaxane unit with the spectra of a model polymer that consists of rotaxane, which exhibits a switching behavior opposite to that of an acid/base. The present investigation provides a novel strategy for controlling the conformation of polymers and contributes to the development of novel functional materials.

\section{CONFLICT OF INTEREST}

The authors declare no conflict of interest.

\section{ACKNOWLEDGEMENTS}

This study was supported by a KAKENHI on Innovative Areas (Coordinating Programming Area 2011, No. 22108510) from MEXT, Japan, and by a JSPS Fellowship for Young Scientists (SS).

1 Sauvage, J. P. \& Dietrich-Buchecker, C. (eds) Molecular Catenanes, Rotaxanes and Knots: A Journey Through the World of Molecular Topology (Wiley-VCH Verlag GmbH, Weinheim, Germany, 1999).

2 Schalley, C. A., Wellandt, T., Brueggmann, J. \& Vögtle, F. Hydrogen-bond-mediated template synthesis of rotaxanes, catenanes, and knotanes. Top. Curr. Chem. 248, 141-200 (2005)

3 Raymo, F. M. \& Stoddart, J. F. in Supramolecular Organization and Materials Design (ed. Jones, W. \& Rao, C. N. R.) Ch. 10, 332-362 (Cambridge University Press, Cambridge, UK, 2008)

4 Yang, W., Li, Y., Liu, H., Chi, L. \& Li, Y. Design and assembly of rotaxane-based molecular switches and machines. Small 8, 504-516 (2012).

5 Balzani, V., G-Lopez, M. \& Stoddart, J. F. Molecular machines. Acc. Chem. Res. 31 , 405-414 (1998).

6 Rescifina, A., Zagni, C., lannazzo, D. \& Merino, P. Recent developments on rotaxanebased shuttles. Curr. Org. Chem. 13, 448-481 (2009).

7 Rescifina, A., Chiacchio, U., Corsaro, A. \& Romeo, G. Recent development on rotaxanebased shuttles: an update to 2010. Curr. Org. Chem. 16, 127-160 (2012).

8 Nakazono, K., Kuwata, S. \& Takata, T. Crown ether-tert-ammonium salt complex fixed as rotaxane and its derivation to nonionic rotaxane. Tetrahedron Lett. 49, 2397-2401 (2008).

9 Suzuki, S., Nakazono, K. \& Takata, T. Selective transformation of a crown ether/secammonium salt-type rotaxane to $\mathrm{N}$-alkylated rotaxanes. Org. Lett. 12, 712-715 (2010)

10 Liu, Y., Flood, A. H., Bonvallet, P. A., Vignon, S. A., Norhrop, B. H., Tseng, H. R., Jeppesen, J. O., Huang, T. J., Brough, B., Baler, M., Magonov, S., Solares, S. D. Goddard, W. A., Ho, C.-M. \& Stoddart, J. F. Linear artificial molecular muscles. J. Am. Chem. Soc. 127, 9745-9759 (2005).

11 Green, J. E., Choi, J. E., Boukai, A., Bunimovich, Y., J-Halperin, E., Delonno, E., Luo, Y., Sheriff, B. A., Xu, K., Skin, Y. S., Tseng, H.-R. \& Stoddart, J. F. A 160-kilobit molecular electronic memory patterned at 1011 bits per square centimeter. Nature 445, 414-417 (2007).

12 Berna, J., Leigh, D. A., Lubomska, M., Mendoza, S. M., Perez, E. M., Rudolf, P., Teobaldi, G. \& Zerbetto, F. Macroscopic Transport by synthetic molecular machines. Nat. Mater. 4, 704-710 (2005).

13 Gibson, H. W. \& Engen, B. P. Rotaxanes, catenanes, polyrotaxanes, polycatenanes and related materials. Prog. Polym. 19, 843-945 (1994).

14 Huang, F. \& Gibson, H. W. Polypseudorotaxanes and polyrotaxanes. Prog. Polym. 30 982-1018 (2005).

15 Harada, A., Hashidzume, A., Yamaguchi, H. \& Takashima, Y. CD-based polymeric rotaxanes. Chem. Rev. 109, 5974-6023 (2009).

16 Fang, L., Olson, M. A., Benıtez, D., Tkatchouk, E., Goddard, W. A. III \& Stoddart, J. F. Mechanically bonded macromolecules. Chem. Soc. Rev. 39, 17-29 (2010).

17 Tomatsu, I., Hashidzume, A. \& Harada, A. Cyclodextrin-based Side-chain polyrotaxane with unidirectional inclusion in aqueous media. Angew. Chem. Int. Ed. 45, 4605-4608 (2006)

$18 \mathrm{Hu}$, J., Hashidzume, A. \& Harada, A. Photoregulated Switching of the recognition site of $\alpha$-cyclodextrin in a side chain polyrotaxane bearing two recognition sited linked with oligo(ethyleneglycol). Macromol. Chem. Phys. 212, 1032-1038 (2011).

19 Bottri, G., Leigh, D. A. \& Shuttle, E. Chiroptical switching in a bistable molecular shuttle. J. Am. Chem. Soc. 125, 13360-13361 (2003).

20 Leigh, D. A., Angeles, M., Morals, F., Perez, E. M., Wong, J. K. Y., Saiz, C. G. Slawin, A. M. Z., Carmichael, A. J., Haddleton, D. M., Brouwer, A. M., Buna, W. J., Wurpel, G. W. H., Leon, S. \& Aerbetto, F. Patterning through controlled submolecular motion: rotaxane-based switches and logic gates that function in solution and polymer film. Angew. Chem. Int. Ed. 44, 3062-3067 (2005).

21 Born, M. \& Ritter, H. Tomb-like rotaxane polymers containing non-covalently bound cyclodextrins in the side chains. Macromol. Chem. Rapid Commun. 12, 471-476 (1991)

22 Takata, T., Kawasaki, H., Asai, S., Kihara, N. \& Furusho, Y. Radically polymerizable pseudorotaxane monomers: versatile building units for side chain polyrotaxane synthesis. Chem. Lett. 28, 111-112 (1999).

23 Takata, T., Hasegawa, T., Kihara, N. \& Furusho, Y. Synthesis of side-chain polyrotaxane via radical polymerizations of vinylic pseudorotaxane monomers having paraquat-type macrocycle as a wheel component. Polym. J. 36, 927-932 (2004).

24 Nakazono, K., Fukasawa, K., Sato, T., Koyama, Y. \& Takata, T. Synthesis of acetylenefunctionalized [2]rotaxane monomers directed toward side chain-type polyrotaxane. Polym. J. 42, 208-215 (2010)

25 Suzaki, Y., Murata, S. \& Osakada, K. Ferrocene-containing side chain polyrotaxanes obtained by radical copolymerization of styrenes with acrylamide with a [2] rotaxane structure. Chem. Lett. 38, 356-357 (2009).

26 Yu, G., Suzaki, Y., Abe, T. \& Osakada, K. Introduction of ferrocene-containing [2]roaxanes onto siloxane, silsesquioxane and polysiloxanes via click chemistry. Dalton Trans. 42, 1476-1482 (2013).

27 Ishiwari, F., Fukasawa, K., Sato, T., Nakazono, K., Koyama, Y. \& Takata, T. A rational design for the directed helicity change of polyacetylene using dynamic rotaxane 
mobility by means of through-space chirality transfer. Chem. Eur. J. 17, 12067-12075 (2011).

28 Ishiwari, F., Nakazono, K., Koyama, Y. \& Takata, T. Rational control of a polyacetylene helix by a pendant rotaxane switch. Chem. Commun. 47, 11739-11741 (2011).

29 Suzuki, S., Ishiwari, F., Nakazono, K. \& Takata, T. Reversible helix-random coil transition of poly ( $m$-phenylene diethynylene) by a rotaxane switch. Chem. Commun. 48, 6478-6480 (2012).

30 Hill, D. J., Mio, M. J., Prince, R. B., Hughes, T. S. \& Moore, J. S. A field guide to foldamers. Chem. Rev. 101, 3893-4011 (2001).

31 Juwarker, H. \& Jeong, K.-S. Anion-controlled foldamers. Chem. Soc. Rev. 39, 3664-3673 (2010).

32 Yashima, E., Maeda, K., lida, H., Furusho, Y. \& Nagai, K. Helical polymers: synthesis, structures, and functions. Chem. Rev. 109, 6102-6211 (2009).

33 Nelson, J. C., Saven, J. G., Moore, J. S. \& Wolynes, P. G. Solvophobically driven folding of nonbiological oligomers. Science 277, 1793-1796 (1999).

34 Prince, R. B., Brunsveld, L., Meijer, E. W. \& Moore, J. S. Twist sense bias induced by chiral side chains in helically folded oligomers. Angew. Chem. Int. Ed. 39, 228-230 (2000).

35 Kijima, M., Tanimoto, H. \& Shirakawa, H. Poly(arylenebutadiynylene)s as high-yield carbonaceous precursor polymers. Synthetic Metals 119, 353-354 (2001).

36 Kijima, M., Tanimoto, H., Takakura, K., Fujiya, D., Ayuta, Y. \& Matsuishi, K. Characterization of porous carbonaceous materials derived from poly(phenylenebutadienylene)s. Carbon 45, 594-601 (2007).

37 Sakai, R., Nagai, A., Tago, Y., Sato, S., Nishimura, Y., Arai, T., Satoh, T. \& Kakuchi, T. Fluorescence turn-on sensing of anions based on disassembly process of urea-functionalized poly(phenylenebutadiynylene) aggregates. Macromolecules 45, 4122-4127 (2012).

38 Kawasaki, H., Kihara, N. \& Takata, T. High yielding and practical synthesis of rotaxanes by acylative end-capping catalyzed by tributylphosphine. Chem. Lett. 10, 1015-1016 (1999).
39 Ashton, P. R., Chrystal, E. J. T., Glink, P. T., Menzer, S., Schiavo, C., Spencer, N., Stoddart, J. F., Tasker, P. A., White, A. J. P. \& Williams, D. J. Pseudorotaxanes formed between secondary dialkylammonium salts and crown ethers. Chem. Eur. J. 2, 709-728 (1996).

40 Tachibana, Y., Kawasaki, H., Kihara, N. \& Takata, T. Sequential O- and N-acylation protocol for high-yield preparation and modification of rotaxanes: synthesis, functionalization, structure, and intercomponent interaction of rotaxanes. J. Org. Chem. 71, 5093-5104 (2006).

41 Hay, A. S. Oxidative coupling of acetylenes. J. Org. Chem. 25, 1275-1276 (1960).

42 Hay, A. S. Oxidative coupling of acetylenes II. J. Org. Chem. 27, 3320-3321 (1962)

43 Bloomfield, V. A., Crothers, D. M. \& Tinoco, I. in Physical Chemistry of Nucleic Acids 83-102 (Harper \& Row, New York, NY, USA, 1974).

44 Cantor, C. R. \& Schimmel, P. R. in Biophysical Chemistry Part II, Techniques for the Study of Biological Structure and Function 399-404 (W. H. Freeman, San Francisco, CA, USA, 1980).

45 Tobe, Y., Utsumi, N., Kawabata, K., Nagano, A., Adachi, K., Araki, S., Sonoda, M., Hirose, K. \& Naemura, K. m-diethynylbenzene macrocycles: syntheses and self-association behavior in solution. J. Am. Chem. Soc. 124, 5350-5364 (2002).

46 Tan, C., Pinto, M. R., Kose, M. E., Chiviriga, I. \& Schanze, K. S. Solventinduced self-assembly of a meta-linked conjugated polyelectrolyte. helix formation, guest intercalation, and amplified quenching. Adv. Mater. 16, 1208-1212 (2004).

47 Zhao, X. \& Schanze, K. meta-linked poly(phenylene ethynylene) conjugated polyelectrolyte featuring a chiral side group: helical folding and guest binding. Langmuir 22, 4856-4862 (2006).

48 Nguyen, H. H., McAliley, J. H., Baston, W. R. III \& Bruce, D. A. Molecular design of functionalized $m$-poly(phenylene ethynylene) foldamers: from simulation to synthesis. Macromolecules 43, 5932-5942 (2010).

49 Cao, J., Fyfe, M. C. T. \& Stoddart, J. F. Molecular shuttles by the protecting group approach. J. Org. Chem. 65, 1937-1946 (2000).

Supplementary Information accompanies the paper on Polymer Journal website (http://www.nature.com/pj) 